\title{
Transcriptional profiling and targeted proteomics reveals common molecular changes associated with cigarette smoke-induced lung emphysema development in five susceptible mouse strains
}

\author{
Maciej Cabanski ${ }^{1,3} \cdot$ Brett Fields $^{2} \cdot$ Stephanie Boue $^{1} \cdot$ Natalia Boukharov $^{2}$. \\ Hector DeLeon ${ }^{1}$. Natalie Dror ${ }^{2} \cdot$ Marcel Geertz $^{1,4} \cdot$ Emmanuel Guedj $^{1}$.

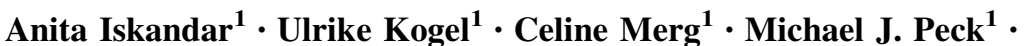 \\ Carine Poussin $^{1} \cdot$ Walter K. Schlage ${ }^{1} \cdot$ Marja Talikka $^{1} \cdot$ Nikolai V. Ivanov $^{1}$ • \\ Julia Hoeng ${ }^{1} \cdot$ Manuel C. Peitsch ${ }^{1}$ \\ Received: 31 July 2014/Revised: 15 March 2015/Accepted: 11 April 2015/Published online: 12 May 2015 \\ (C) The Author(s) 2015. This article is published with open access at Springerlink.com
}

\begin{abstract}
Background Mouse models are useful for studying cigarette smoke (CS)-induced chronic pulmonary pathologies such as lung emphysema. To enhance translation of largescale omics data from mechanistic studies into pathophysiological changes, we have developed computational tools based on reverse causal reasoning (RCR).

Objective In the present study we applied a systems biology approach leveraging RCR to identify molecular mechanistic explanations of pathophysiological changes associated with CS-induced lung emphysema in susceptible mice.

Methods The lung transcriptomes of five mouse models (C57BL/6, ApoE ${ }^{-/-}, \mathrm{A} / \mathrm{J}, \mathrm{CD} 1$, and $\mathrm{Nrf} 2^{-/-}$) were analyzed following 5-7 months of CS exposure.

Results We predicted 39 molecular changes mostly related to inflammatory processes including known key emphysema drivers such as NF- $\mathrm{BB}$ and TLR4 signaling,
\end{abstract}

Responsible Editor: Andrew Roberts.

Electronic supplementary material The online version of this article (doi:10.1007/s00011-015-0820-2) contains supplementary material, which is available to authorized users.

Julia Hoeng

julia.hoeng@pmi.com

1 Philip Morris International Research and Development, Philip Morris Products S.A, Quai Jeanrenaud 5, 2000 Neuchâtel, Switzerland

2 Selventa, One Alewife Center, Cambridge, MA 02140, USA

3 Present Address: Novartis Pharma AG, Novartis Institutes for Biomedical Research (NIBR), 4002 Basel, Switzerland

4 Present Address: Bayer Technology Services GmbH, 51368 Leverkusen, Germany and increased levels of TNF- $\alpha, \mathrm{CSF} 2$, and several interleukins. More importantly, RCR predicted potential molecular mechanisms that are less well-established, including increased transcriptional activity of PU.1, STAT1, $\mathrm{C} / \mathrm{EBP}$, FOXM1, YY1, and N-COR, and reduced protein abundance of ITGB6 and CFTR. We corroborated several predictions using targeted proteomic approaches, demonstrating increased abundance of $\mathrm{CSF} 2, \mathrm{C} / \mathrm{EBP} \alpha, \mathrm{C} / \mathrm{EBP} \beta$, PU.1, BRCA1, and STAT1.

Conclusion These systems biology-derived candidate mechanisms common to susceptible mouse models may enhance understanding of CS-induced molecular processes underlying emphysema development in mice and their relevancy for human chronic obstructive pulmonary disease.

Keywords Emphysema - Cigarette smoke · Systems biology · Mouse models · Gene expression · Molecular mechanisms

\section{Introduction}

Chronic obstructive pulmonary disease (COPD) is a complex pulmonary disorder primarily induced by cigarette smoking and characterized by poorly or not reversible airflow obstruction. The three major clinical manifestations of COPD are emphysema, chronic bronchitis and small airway diseases $[1,2]$. A hallmark of the disease is chronic inflammation in the airways and lungs, which together with protease/anti-protease imbalance, apoptosis and oxidative stress contributes to the progressive tissue damage underlying COPD pathophysiology [3, 4]. Increasing severity of the disease, evidenced by more pronounced airflow obstruction, is measured by spirometry and graded according to the Global Initiative for chronic obstructive lung disease 
(GOLD) criteria (grades I-IV). Grades I and II represent mild and usually early stages of COPD, while grades III and IV correspond to progressively more severe disease stages [2].

Our understanding of emphysema and COPD pathogenesis has evolved considerably over the past 50 years; however, we still have very limited knowledge regarding the complex molecular mechanisms that drive the pathological changes. Although $>90 \%$ of COPD patients are smokers, only $20 \%$ of smokers develop COPD [5, 6] with the underlying reasons for this being complex but likely involving genomic variation as an important determinant of disease susceptibility [7]. In mice, CS-related pulmonary changes also have a genetic component, evidenced by the fact that different strains display varying susceptibility to CS exposure and emphysema development [8-10]. It has been proposed that differential susceptibility or resistance of these strains to CS exposure may be due to the varying degree of activation of signaling pathways such as nuclear factor $(\mathrm{NF})-\kappa \mathrm{B}, \mathrm{p} 38$ mitogen-activated protein kinase or histone deacetylase (HDAC)2 [8-10]. In addition, genetic or pharmacological manipulation resulted in identification of many key molecules associated with murine CS-induced emphysema [11]. Several groups, using knock-out and transgenic mice, have clearly demonstrated the importance of multiple genes and pathways, including chemokine/cytokine receptors (e.g. C-C motif receptor (CCR)1, CCR5, CCR6 [12-14]), metalloproteinase enzymes (e.g. MMP-9/ 12 [15]), cytokines (e.g. interleukin (IL)-1 $\beta$, IL-18 [16, 17]), and transcription factors (TFs) such as NF- $\kappa \mathrm{B}$ [18], nuclear factor erythroid 2-related factor $2 \mathrm{Nrf} 2$ [19] or activator protein (AP)-1 [20]).

Although these studies have increased our understanding of emphysema development and progression, they have several potential limitations with respect to identification of precise molecular mechanisms. For example, the approaches were mostly focused on single gene analysis or characterization of cellular, inflammatory or histopathological changes without attempting a more comprehensive mechanistic investigation using multi-omics technologies. Remarkably, only a few studies have investigated global gene expression profiles associated with the development or progression of murine CS-induced emphysema [19, 21-24]. Considering that COPD is a highly heterogeneous and polygenic disease, a more comprehensive and powerful approach that translates these large-scale data sets into pathophysiological changes is essential to enhance understanding of the molecular mechanisms that induce alveolar destruction and subsequent emphysema. For instance, we recently applied Reverse Engineering and Forward Simulation (REFS ${ }^{\mathrm{TM}}$ ) technology to identify key molecular drivers of emphysema in $\mathrm{A} / \mathrm{J}$ mice by integrating the whole genome expression data and COPD-relevant endpoints [25].
In the current study, we comprehensively investigated the lung transcriptomes leveraging the RCR [26] methodology to evaluate molecular mechanisms underlying emphysematous changes. Among the 39 predictions that were common to the five strains/genotypes investigated, we identified mechanisms known to be associated with emphysema including $\mathrm{NF}-\kappa \mathrm{B}$ signaling, Toll-like receptor (TLR4) signaling, and increased protein abundance of inflammatory mediators such as tumor necrosis factor (TNF)$\alpha$, colony stimulating factor 2 (granulocyte-macrophage) (CSF2), as well as several interleukins. More importantly, we predicted a series of mechanisms for which a role in emphysema development is not yet well documented, e.g. transcriptional activity of spleen focus forming virus (SFFV) proviral integration oncogene (SFPI1, aka.PU.1), signal transducers and activators of transcription (STAT)-1, CCAAT/enhancer-binding protein (C/EBP), forkhead box M1 (FOXM1), Yin and Yang (YY)-1, nuclear receptor corepressor (N-COR), increased protein expression of IL17 , or decreased protein expression of integrin Beta-6 (ITGB6) and cystic fibrosis transmembrane conductance regulator (CFTR). The present study contributes to a better understanding of the specific CS-induced molecular processes underlying emphysema development in mice by elucidating novel effectors implicated in disease progression, which could also be relevant in human COPD.

\section{Materials and methods}

\section{Transcriptomics data sets}

Transcriptomics data sets were derived from four mouse CS-inhalation studies: C57BL/6 [27], apolipoprotein Edeficient $\left(\mathrm{ApoE}^{-} /^{-}\right.$) C57BL/6 mice [28], A/J mice [25], CD1 and nuclear factor erythroid 2-related factor 2-deficient CD1 mice (Nrf2 ${ }^{-} /^{-}$) [29]. The exposure studies, three of which have been published in detail previously, were conducted in Philip Morris Research Laboratories at different times and locations under similar mainstream CS exposure protocols (Table 1). RNA was isolated from either whole lung (C57BL/6, $\mathrm{ApoE}^{-/-}, \mathrm{Nrf}^{-/-}$, and CD1 mice) or lung parenchyma by laser capture microdissection $(\mathrm{A} / \mathrm{J}$ and $\mathrm{ApoE} \mathrm{E}^{-/-}$mice). In case of $\mathrm{C} 57 \mathrm{BL} / 6$ mice, genomewide expression profiling of whole lung was conducted at 1 , 3,5 , and 7 months in the sham (air exposed) and CS groups (for experimental details, see below). Affymetrix CEL files that passed the quality check were used for further data processing and are publicly available: Gene Expression Omnibus (GSE18344) for the $\mathrm{CD} 1 / \mathrm{Nrf}^{-} /^{-}$mice, Array Express (E-MTAB-1390) for the C57BL/6 $\mathrm{ApoE}^{-} /^{-}$mice, Array Express (E-MTAB-1426) for the A/J mice, and Array Express (E-MTAB-2756) for the C57BL/6 mice. 
Table 1 Comparison of four cigarette smoke exposure studies

\begin{tabular}{|c|c|c|c|c|}
\hline $\begin{array}{l}\text { Mouse strain } \\
\text { Provider }\end{array}$ & $\begin{array}{l}\text { C57BL/6 } \\
\text { Charles River, USA }\end{array}$ & $\begin{array}{l}\mathrm{ApoE}^{-/-}(\mathrm{C} 57 \mathrm{BL} / 6 \\
\text { background }) \\
\text { Taconic, Denmark }\end{array}$ & $\begin{array}{l}\text { A/J } \\
\text { The Jackson Laboratory, } \\
\text { USA }\end{array}$ & $\begin{array}{l}\left.\text { Nrf2 }{ }^{-1-} \text { (CD1 background }\right) \\
\text { and CD1 } \\
\text { RIKEN BRC, Japan }\end{array}$ \\
\hline Age at start (weeks) & $\sim 8-9$ & $\sim 5-9$ & $\sim 10-15$ & $\sim 12-13$ \\
\hline Treatment & Fresh air/3R4F & Fresh air/3R4F & Fresh air/3R4F & Fresh air/2R4F \\
\hline \multicolumn{5}{|l|}{ Exposure duration } \\
\hline Hours/day & 4 & 3 & 4 & 4 \\
\hline Days/week & 5 & 5 & 5 & 5 \\
\hline Months & $1,3,5,7$ & 6 & 5 & 5 \\
\hline Smoking parameters & $\begin{array}{l}\text { Health Canada Intense } \\
\text { (HCI) }\end{array}$ & $\begin{array}{l}\text { Health Canada Intense } \\
\quad \text { (HCI) }\end{array}$ & ISO 3308 & ISO 3308 \\
\hline Concentration $\left(\mathrm{mg}\right.$ TPM $\left./ \mathrm{m}^{3}\right)$ & 750 & 600 & 750 & 750 \\
\hline Origin of gene expression data & Whole lung & $\begin{array}{l}\text { Whole lung or lung } \\
\text { parenchyma }\end{array}$ & Lung parenchyma & Whole lung \\
\hline References & $\begin{array}{l}\text { Hoeng et al. [27] and } \\
\text { unpublished }\end{array}$ & Boue et al. [28] & $\begin{array}{l}\text { Xiang et al. [25] and } \\
\text { unpublished }\end{array}$ & Gebel et al. [29] \\
\hline \multirow{2}{*}{$\begin{array}{l}\text { Dataset accession number and } \\
\text { Database }\end{array}$} & E-MTAB-2756 & E-MTAB-1390 & E-MTAB-1426 & GSE18344 \\
\hline & ArrayExpress & ArrayExpress & ArrayExpress & GEO \\
\hline
\end{tabular}

$A p o E$ apolipoprotein E, Nrf2 nuclear factor, erythroid-derived 2, like 2

\section{Animals and CS exposure}

Care and use of the mice was in conformity with the American Association for Laboratory Animal Science Policy on the Humane Care and Use of Laboratory Animals (http://www.aalas.org/). Animal experiments were approved by the Institutional Animal Care and Use Committee of Philip Morris Research Laboratories, Belgium or Singapore (C57BL/6 study).

Although the studies were conducted at different times, the smoke exposure conditions utilized in the studies were largely conserved (Table 1). The Standard Reference Cigarette $3 \mathrm{R} 4 \mathrm{~F}$ was obtained from the Tobacco and Health Institute at the University of Kentucky. It is a filter cigarette with reported mainstream smoke yields per cigarette of $11.0 \mathrm{mg}$ total particulate matter (TPM), $0.73 \mathrm{mg}$ nicotine, and $12.0 \mathrm{mg}$ carbon monoxide (CO) (http://www2.ca.uky. edu/refcig/3R4F\%20Preliminary\%20Analysis.pdf). All cigarettes were conditioned and smoked according to International Organization for Standardization or Health Canada Intense parameters [28, 30, 31]. Mainstream CS was diluted with filtered conditioned air to a target concentration of $750 \mathrm{mg} \mathrm{TPM} / \mathrm{m}^{3}$, unless otherwise noted (Table 1).

The C57BL/6 study was conducted as a seven-month smoke inhalation study using female C57BL/6 mice approximately 8-9 weeks of age at study commencement. Mice (eight per group) were exposed in whole-body chambers to diluted mainstream CS at a target concentration of $750 \mathrm{mg} \mathrm{TPM} / \mathrm{m}^{3}$ for $4 \mathrm{~h}$ per day, 5 days per week, with intermittent exposure to fresh filtered air for $30 \mathrm{~min}$ after the first hour of smoke exposure and for $60 \mathrm{~min}$ after the second and third exposure hours to avoid a build-up of excessive carboxyhemoglobin $(\mathrm{COHb})$ concentrations. An initial 2-week concentration adaptation period was implemented. Sham control animals were exposed to conditioned fresh air. Dissection was performed at the end of the scheduled exposure periods (1, 3, 5, and 7 months), 18-24 h after the last exposure. Lungs were snap-frozen, and for each lung tissue sample, 22 slices (each $20 \mu \mathrm{m}$ ) were cut using a cryostat and RNA was extracted, processed, and analyzed as previously described [25, 32].

The A/J mouse study [25] was conducted as a 5-month CS inhalation study using female A/J mice approximately $10-15$ weeks of age at study commencement. Mice were exposed to diluted mainstream CS at a target concentration of $750 \mathrm{mg} \mathrm{TPM} / \mathrm{m}^{3}$ for $4 \mathrm{~h} /$ day. After 5 months, lung parenchyma and airway samples were collected using laser-capture microdissection as described [33] from CSexposed mice and sham control mice exposed to conditioned fresh air. The presence of emphysema was histologically confirmed.

The $\mathrm{ApoE}^{-/^{-}}$mouse study [28] was conducted as a sixmonth CS inhalation study using female $\mathrm{ApoE}^{-/^{-}}$mice approximately 5-9 weeks of age at study commencement. Animals were exposed to diluted mainstream CS at a target concentration of $600 \mathrm{mg} \mathrm{TPM} / \mathrm{m}^{3}$. Following 6 months of exposure, whole lung and isolated parenchyma were collected from CS-exposed mice and sham control mice exposed to conditioned fresh air. The presence of emphysema was histologically confirmed. 
The $\mathrm{Nrf}^{-}{ }^{-}$study [34] was conducted as a 5-month smoke exposure study using both female $\mathrm{Nrf}_{2}{ }^{-} I^{-}$mice and wild-type littermates on the CD1 background that were approximately $12-13$ weeks of age at study commencement. Animals were exposed to diluted mainstream CS at a target concentration of $750 \mathrm{mg} \mathrm{TPM} / \mathrm{m}^{3}$ for $4 \mathrm{~h} /$ day, 5 days per week. Whole lung samples were collected after a 5-month CS-exposure. The presence of emphysema was histologically confirmed.

\section{Reverse causal reasoning}

RCR interrogates a literature-based Knowledge Assembly Model (KAM; a collection of biological concepts and entities, and their causal relationships), to identify upstream controllers of gene expression changes (so called State Changes) observed in the transcriptomic data set [26]. For all of the data set analysis, the full Selventa Knowledgebase consisting of causal connections curated from multiple species and contexts (e.g. human, mouse, and rat) served as the KAM to interrogate the State Changes. The potential upstream controllers identified by RCR are termed "hypotheses" (HYPs) and are statistically significant potential explanations for observed mRNA State Changes. Each HYP is scored according to two probabilistic metrics, richness and concordance. Richness is the probability that the number of observed mRNA State Changes connected to a given HYP could have occurred by chance alone, calculated using the hypergeometric distribution. Concordance is the probability that the number of observed mRNA State Changes connected to the HYP occur in the proper direction as predicted in the KAM (e.g. increased or decreased activity, or abundance of a node), when compared to chance alone, calculated using the binomial distribution. The HYPs with $P<0.05$ for richness and concordance were considered statistically significant.

To highlight patterns of significance of the concordance values over time or across mouse strains, common HYPs were grouped using a hierarchical clustering approach. The clustering was performed using the Euclidean distance as dissimilarity metrics calculated with the minus $\log _{10^{-}}$ transformed concordance $P$ values between each pair of HYPs and the "median" as agglomerative method. The minus $\log _{10}$-transformed concordance $P$ values were multiplied by the sign of the concordance scores to provide the directionality of regulation of the predicted upstream controller (HYPs).

\section{Lung histomorphometry}

Alveolar emphysema was assessed by mean chord length (Lm) measurements, as described previously [28]. Briefly, several step serial sections per animal, representing a cross section along the left main stem bronchus and its branching bronchioles, was selected for morphometric evaluation. $\mathrm{Lm}$ measurements were performed on images captured with an Axio-Imager-Z1 microscope equipped with an 8-specimen holder, a high-resolution digital color camera (Olympus DP70) and VIS-software from Visiopharm (Horsholm, Denmark). All measurements were conducted according to Visiopharm's quantitative digital pathology methods.

\section{Bronchoalveolar lavage fluid (BALF) collection and analysis}

BALF was collected as previously described [28]. Cell-free BALF supernatants were analyzed by Myriad Rules-Based Medicine (Myriad RBM, Austin, TX, USA) using a Rodent MAP 2.0 antibody array with 59 analytes/biomarkers (http:// rbm.myriad.com/products-services/rodentmap-services/ rodentmap/). Analyte measurements below the least detectable dose (LDD) or the lower limit of quantification (LLOQ) were substituted by $\max$ (LDD, LLOQ) and divided by two. Six analytes (FGF-9, GST-alpha, IFNgamma, IL-17A, IL-3, and SGOT) were excluded from the analysis since they were largely below the detection/quantification limits.

\section{Reverse phase protein array (RPPA) analysis}

The TissueLyser II (Qiagen, Hilden, Germany) bead-mill disruption system was used for protein extraction from cryosliced right lung tissue samples, which were obtained from a confirmatory follow-up study with the same exposure conditions. Protein extraction was performed according to the manufacturer's instructions, using one $5-\mathrm{mm}$ steel bead (Qiagen) and $400 \mu \mathrm{l}$ Zeptosens cell lysis buffer (CLB1, Bayer Technology Services GmbH, Leverkusen, Germany). After extraction, the sample was centrifuged in a microcentrifuge for $10 \mathrm{~min}$ at $14,000 \mathrm{rpm}$, and the cleared supernatant was transferred into fresh tubes for further analysis. Protein concentration of collected supernatants was quantified as described [35] using a fluorescence-based protein microspot assay [EZQ ${ }^{\mathrm{TM}}$ Protein Quantitation Kit (Life Technologies ${ }^{\mathrm{TM}}$, Logan, UT, USA)]. Protein extracts were stored at $-80{ }^{\circ} \mathrm{C}$ until further use.

Analysis of protein extracts by Zeptosens ${ }^{\circledR}$ RPPA technology was performed as previously described [36]. Protein extracts were adjusted to uniform concentrations with CLB1 buffer. Adjusted extracts were further diluted with CLB1 buffer to a final spotting concentration of $0.1 \mu \mathrm{g} / \mu \mathrm{l}$. Diluted extracts were printed at four serial dilutions (1.6-fold) onto Zeptosens ${ }^{\circledR}$ hydrophobic chips (Bayer Technology Services GmbH) using a microarray printer (NanoPlotter 2.1, GeSiM, Grosserkmannsdorf, Germany). Each sample was processed in technical 
duplicates with independent dilutions on separate arrays, i.e. eight spots per sample with four spots per array. Following array printing, arrays were blocked, washed, and dried according to the manufacturer's specifications and stored at $4{ }^{\circ} \mathrm{C}$ in dark until further use.

For measurement of protein signals, arrays were incubated overnight at room temperature in primary antibodies at dilutions of 1:500 in CAB1 assay buffer (Bayer Technology Services $\mathrm{GmbH}$ ). The following primary antibodies were used: anti-BRCA1 (sc646, Santa Cruz Biotechnology, Dallas, TX, USA), anti-C/EBP $\alpha$ (sc61, Santa Cruz Biotechnology), anti-C/EBP $\beta$ (sc150, Santa Cruz Biotechnology), anti-ITGB6 (sc15329, Santa Cruz Biotechnology), anti-PU.1 (LSC30679, LifeSpan BioSciences, Seattle, WA, USA), antiSOCS3 (04004, Merck Millipore, Darmstadt, Germany), antiSTAT1 (9172, Cell Signaling Technologies, Danvers, MA, USA), and anti-STAT1(Tyr701) (44376G, Life Technologies). Following washing, arrays were incubated for $2 \mathrm{~h}$ with either Alexa647- (Life Technologies) or Dylight650- (BioRad AbD Serotec GmbH, Puchheim, Germany) labeled antispecies secondary antibodies, at dilutions of 1:500. After subsequent washing, stained arrays were imaged using an array scanner (ZeptoREADER, Bayer Technology Services $\mathrm{GmbH}$ ), according to the manufacturer's recommendations. For correction of anti-species secondary antibody staining, arrays were assayed in the absence of primary antibodies. For measurement of spotted protein amounts, one blank chip (i.e. without antibody incubation) was stained with SYPRO ${ }^{\circledR} \mathrm{Ru}-$ by. Scanned images were analyzed using ZeptoVIEW 3.1 software (Bayer Technology Services GmbH). Normalized fluorescence intensities (NFI) for each sample and protein target were calculated as reference fluorescence intensities of primary antibody stained arrays (RFIprimary) corrected for secondary antibody staining (RFIsecondary), as well as relative spotted protein concentration (RFIprotein), determined by (RFIprimary-RFIsecondary)/RFIprotein, using the Zepto VIEW 3.1 software. NFI values were used for subsequent analysis.

\section{Statistical analysis}

For BALF analysis (MAP), RPPA, and histomorphometry, two-tailed $t$ tests were performed, assuming unequal variance.

\section{Results}

\section{Identification of potential mechanistic explanations of CS-induced emphysema}

To determine the molecular mechanisms underlying CSinduced lung emphysema, we applied RCR to transcriptomic data sets derived from lungs of five mouse genotypes (C57BL/6, $\mathrm{ApoE}^{-/-}, \mathrm{A} / \mathrm{J}, \mathrm{Nrf}^{-/-}$and $\mathrm{CD} 1$ ), susceptible to emphysema development following a prolonged (5-6 months) exposure to CS. We and others have already demonstrated that exposure to CS leads to increased mean chord length $(\mathrm{Lm})$ in CD1 $(12.5 \%)$, Nrf2 $2^{-1-}$ (16\%), and $\mathrm{ApoE}^{-1-}(17.1 \%)$ mice $[19,28,29]$. In addition, long-term exposure to CS (5 months) resulted in significant increase in the $\mathrm{Lm}$ in $\mathrm{A} / \mathrm{J}(14 \%)$ and C57BL/6 (44.9\%) mice (Fig. 1).

As described previously, RCR is a computational methodology that uses a set of differentially measured biological entities (e.g. mRNA) as inputs to make predictions (called "HYPs") about the identity of potential upstream controllers of observed differential measurements [26]. For example, HYPs can refer to biological entities such as protein abundance, regulatory mechanisms such as activities of receptors, transcription factors, or kinases. By comparing six data sets, we identified 39 predicted HYPs that were conserved across five genotypes (Fig. 2, Supplementary File 1). Another 37 common HYPs (Supplementary File 1) were also predicted to be regulated. They were related to biological processes (e.g. Natural killer cell activation, T-helper 2 cell differentiation) or were proxies that represented mechanisms using experimental perturbations (Ovalbumin, Sirolimus, Bleomycin, etc.), and were not currently considered for the experimental verification. Out of the selected HYPs related to biological entities, 28 were predicted to increase, and 11 predicted to decrease. The majority of HYPs were related to the inflammatory response and mapped to nine sub-networks, lung-specific Inflammatory Process Network model [37] and Tissue Repair and Angiogenesis Network model [38], consisting of the following submodels: Tissue Damage, Neutrophil Response and Chemotaxis, Mucus Hypersecretion, Macrophage Mediated Recruitment, Macrophage Activation, Immune Regulation of Tissue Repair, Immune
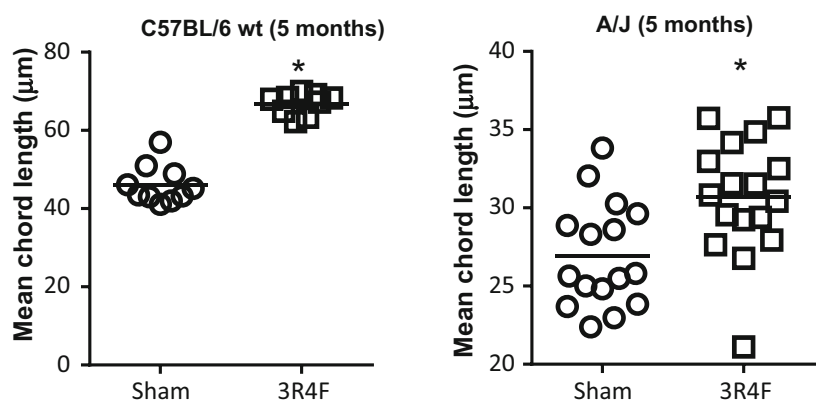

Fig. 1 Mean chord length (Lm) in C57BL/6 (left) and A/J (right) mice exposed to fresh air (sham) or cigarette smoke $(3 \mathrm{R} 4 \mathrm{~F})$ for 5 months. Individual values are presented ( $n=10-17$ per group). The exposure regime is described in "Materials and methods". $* P \leq 0.05$ (3R4F vs. sham) 
Fig. 2 Common HYPs across five mouse models exposed to cigarette smoke for 5-6 months. Results are shown as hierarchically clustered colorcoded heatmap according to HYP concordance and richness (3R4F/2R4F vs. sham comparison is shown). Yelloworange to blue gradient indicates predicted increase and decrease in abundance or activity of HYPs. Catof, catalytic activity of; kaof, kinase activity of; taof, transcriptional activity of; paof, phosphatase activity of; gtpof, GTP-binding activity of. Lwhole lung, $\mathrm{P}$-lung parenchyma (prepared by laser capture microdissection) (color figure online)

\begin{tabular}{|c|c|c|c|c|c|c|}
\hline $7.0 e-07$ & $7.0 e-00$ & $1.3 e-03$ & $2.4 e-03$ & 8. $1 e^{-11}$ & 7.1e-05 & $\| 1 \mathbf{b}$ \\
\hline $1.1 \mathrm{e}-07$ & $1.4 \mathrm{e}-\infty \mathrm{e}$ & $3.2 \mathrm{e}-03$ & 4.1e-04 & $0.00-00$ & $5.4 \mathrm{e}-03$ & Csf2 \\
\hline $2.4 e-00$ & $0.3 e-06$ & $5.8 \mathrm{e}-08$ & $3.8 e-04$ & $6.00-10$ & 2.1e-04 & taof(NFKB Complex Mm) \\
\hline 4.1e-07 & $3.2 \mathrm{e}-05$ & $1.8 e-07$ & $2.5 e-03$ & $5.2 \mathrm{e}-07$ & $7.80-03$ & $\| 13$ \\
\hline $2.5 e-04$ & $5.4 \mathrm{e}-03$ & $7.1 e-04$ & $2.3 e-02$ & $1.20-04$ & $2.3 e-02$ & Hif1a \\
\hline 2.8e-04 & $1.2 \mathrm{e}-04$ & $3.20-03$ & 3.1e-02 & $26 e-04$ & $1.2 \mathrm{e}-03$ & catof(Ccr3) \\
\hline $1.5 e-02$ & $6.3 e-02$ & 3.1e-02 & $0.3 e-02$ & $1.80-03$ & $1.8 \mathrm{e}-02$ & Myd88 \\
\hline $7.8 e-03$ & $3.5 \mathrm{e}-02$ & $1.8 e-02$ & $1.80-02$ & $6.60-04$ & $8.5 e-03$ & kaof(Chuk) \\
\hline $6.5 e-03$ & $2.8 \mathrm{e}-02$ & $6.5 e-03$ & $4.6 e-02$ & $200-03$ & $4.5 \mathrm{e}-02$ & taof(Rel) \\
\hline $8.5 e-02$ & 1.1e-02 & $3.2 \mathrm{e}-03$ & $3.3 e-02$ & $8.5 e-03$ & $1.8 e-02$ & 1120 \\
\hline $6.8 e-03$ & 9.1e-04 & $3.7 \mathrm{e}-02$ & $1.00-02$ & $1.80-02$ & $1.1 e-02$ & taof(Cebpa) \\
\hline $1.1 e-02$ & $2.2 \mathrm{e}-02$ & 4.8e-03 & $4.7 e-04$ & $1.00-02$ & $1.8 e-02$ & taof(Cebpb) \\
\hline $1.2 \mathrm{e}-02$ & $4.4 \mathrm{e}-02$ & 1.1e-03 & $1.0 \mathrm{e}-02$ & $5.6 e-03$ & $5.4 e-08$ & ||12a:II12b \\
\hline $1.5 e-04$ & $4.9 \mathrm{e}-02$ & $6.5 e-03$ & 2.1e-03 & $6.0 \mathrm{e}-03$ & $6.0 e-08$ & Brca1 \\
\hline 1.1e-02 & $8.2 e-02$ & $1.7 \mathrm{e}-02$ & 1.1e-02 & 5.1e-05 & $3.5 \mathrm{e}-05$ & taof(Stat1) \\
\hline $7.6 e-06$ & $4.6 \mathrm{e}-02$ & $5.8 e-03$ & $3.5 e-02$ & $1.5 e-08$ & $7.8 e-05$ & $\| 17 f$ \\
\hline $4.9 e-04$ & 2.1e-02 & $2.6 e-02$ & 4.7e-02 & $25 e-08$ & 8.1e-04 & $\| 17 a$ \\
\hline $3.8 e-06$ & $3.8 \mathrm{e}-05$ & $4.20-04$ & $4.80-04$ & $1.5 e-08$ & $1.5 \mathrm{e}-03$ & taof(Cebpd) \\
\hline $3.8 e-06$ & $7.6 \mathrm{e}-0 \mathrm{e}$ & $2.5 e-04$ & $8.8 \mathrm{e}-04$ & 9.8e-08 & $1.7 e-05$ & Foxm1 \\
\hline $1.1 \mathrm{e}-02$ & 1.1e-04 & $2.7 e-04$ & $2.7 e-04$ & $1.2 \mathrm{e}-0 \mathrm{e}$ & $3.2 \mathrm{e}-03$ & Casp4 \\
\hline $7.6 e-06$ & $3.3 e-08$ & $1.2 e-07$ & $6.2 \mathrm{e}-08$ & $4.5 e-05$ & 4.8e-04 & Gfap \\
\hline $2 \cdot 2 e-12$ & 8. $1 e-\infty 8$ & $8.3 e-08$ & $2.8 e-08$ & $24 e-08$ & $1.8 e-02$ & IFNalpha Family Mm \\
\hline $1.7 \mathrm{e}-04$ & $1.0 \mathrm{e}-03$ & $1.6 e-07$ & $1.0 e-04$ & $28 e-14$ & $1.4 e-05$ & Ifing \\
\hline $1.4 e-02$ & $4.8 \mathrm{e}-02$ & $3.0 e-02$ & $5.1 e-02$ & $200-08$ & $1.0 e-08$ & taof(Yy1) \\
\hline $1.2 \mathrm{e}-00$ & $3.8 \mathrm{e}-07$ & $1.8 \mathrm{e}-05$ & $3.2 e-05$ & $2.2 \mathrm{e}-13$ & $1.3 e-13$ & taof(Sfpi1) \\
\hline $5.0 e-18$ & $1.4 \mathrm{e}-05$ & 1.1e-07 & 9.1e-05 & $1.2 e-17$ & $4.8 e-10$ & catof(TIr4) \\
\hline 4.6e-18 & 7.1e-05 & $5.0 e-08$ & $1.5 e-04$ & $1.7 \mathrm{e}-18$ & $1.2 \mathrm{e}-00$ & $\operatorname{catof}(T \mid r 3)$ \\
\hline $3.0 e-17$ & $5.6 e-13$ & $4.3 e-10$ & $0.2 e-00$ & $8.7 e-27$ & $3.6 e-17$ & $\operatorname{Tnf}$ \\
\hline 6.3e-03 & $3.6 \mathrm{e}-03$ & 1.1e-02 & $3.8-02$ & $1.7 e-03$ & $3.0 e-02$ & gtpof(Gna15) \\
\hline $3.8 e-03$ & $5.1 e-05$ & $6.8 \mathrm{e}-02$ & 3.1e-02 & $6.90-03$ & $1.8 e-02$ & Mat1a \\
\hline $7.8 e-03$ & $2.5 e-04$ & 1.1e-02 & $2.5 e-04$ & $6.3 e-03$ & $1.3 e-03$ & Adnp \\
\hline $4.9 e-04$ & $8.3 \mathrm{e}-02$ & $5.4 e-02$ & $1.7 e-02$ & $200-02$ & $1.0 \mathrm{e}-03$ & catof(Cxcr7) \\
\hline $1.5 e-06$ & $7.8 \mathrm{e}-04$ & $3.3 e-03$ & 2.1e-02 & $8.80-05$ & $1.7 e-03$ & $\operatorname{ltg} b 6$ \\
\hline $3.8 \mathrm{e}-03$ & $8.1 e-03$ & $3.5 e-05$ & $5.2 e-05$ & $1.5 \mathrm{e}-0 \mathrm{e}$ & $1.8 \mathrm{e}-02$ & taof(Mkl1) \\
\hline $1.2 \mathrm{e}-07$ & $2.2 \mathrm{e}-03$ & 1.1e-04 & $1.3 e-02$ & $1.5 e-07$ & $1.1 \mathrm{e}-05$ & taof(Ncor1) \\
\hline $4.8 e-07$ & $4.6 e-04$ & $4.6 e-04$ & $4.6 e-04$ & Q.5e-10 & $28 e-08$ & Socs3 \\
\hline $1.0 e-05$ & $1.3 e-05$ & $28 e-08$ & $1.00-08$ & $288-10$ & $1.80-04$ & Dmd \\
\hline $3.5 e-10$ & $1.2 \mathrm{e}-10$ & $28 e^{-12}$ & $3.5 e-10$ & $1.8 e-10$ & $1.80-07$ & Cftr \\
\hline $6.3 e-06$ & $1.4 \mathrm{e}-04$ & $6.3 e-07$ & $5.8 e-00$ & & & paof(Pten) \\
\hline
\end{tabular}

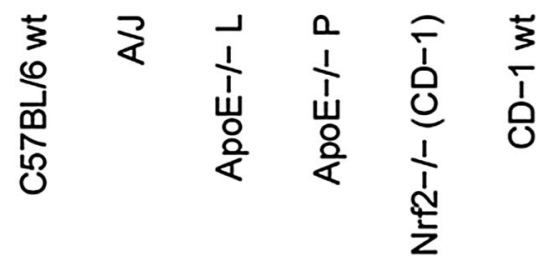

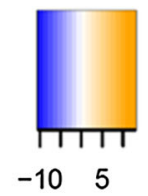

minus $\log _{10}$ (concordance $\mathrm{P}$ value) multiplied by the sign of the concordance score
Regulation of Angiogenesis, Epithelial Proinflammatory Signaling, and Dendritic Cell Activation (Table 2). More specifically, among the common HYPs, we identified increased protein abundance of inflammatory mediators associated with T helper (Th) responses [e.g.TNF- $\alpha$, IFN- $\gamma$, IL-1 $\beta$, colony stimulating factor (CSF)-2, IL-13, IL-17A, and IL-17F]; increased activity of inflammation-related TFs [e.g. NF-кB, STAT-1, Sfpil (known as PU.1)], C/EBP family members $\alpha, \beta$, and $\delta$; and increased receptor activity of CCR3 and Toll-like receptors (TLRs) 3 and 4.

\section{Time-course of the occurrence of common mechanisms in C57BL/6 mice}

Since the comparative RCR analysis was performed crosssectionally on data sets derived from lungs with fully developed emphysema, i.e. at the five-month time-point, we investigated longitudinally the time-course of these commonly identified HYPs as disease-related mechanisms in one strain, i.e. the C57BL/6, from months one to seven. To elucidate whether the predicted mechanisms might be associated with the onset of destructive lung lesions, we analyzed transcriptomic data sets obtained from lungs of air- or smoke-exposed C57BL/6 mice at early time points (months 1 and 3) preceding and accompanying the occurrence of observable anatomic changes associated with emphysema ([21, 39] and unpublished data). Nearly all the HYPs identified in the emphysematous lungs (at 5-6 months) were already statistically significant after the first month of CS exposure (Fig. 3, Supplementary Figure 1), suggesting they could be linked to emphysema onset and progression. Moreover, the majority of HYPs 
Table 2 Common HYPs mapped to subnetworks of the Inflammatory Process Network. Presence of a HYP within a specific subnetwork is indicated by a gray block. Catof, catalytic activity of; kaof, kinase activity of; taof, transcriptional activity of. $\uparrow$, increase; $\downarrow$, decrease

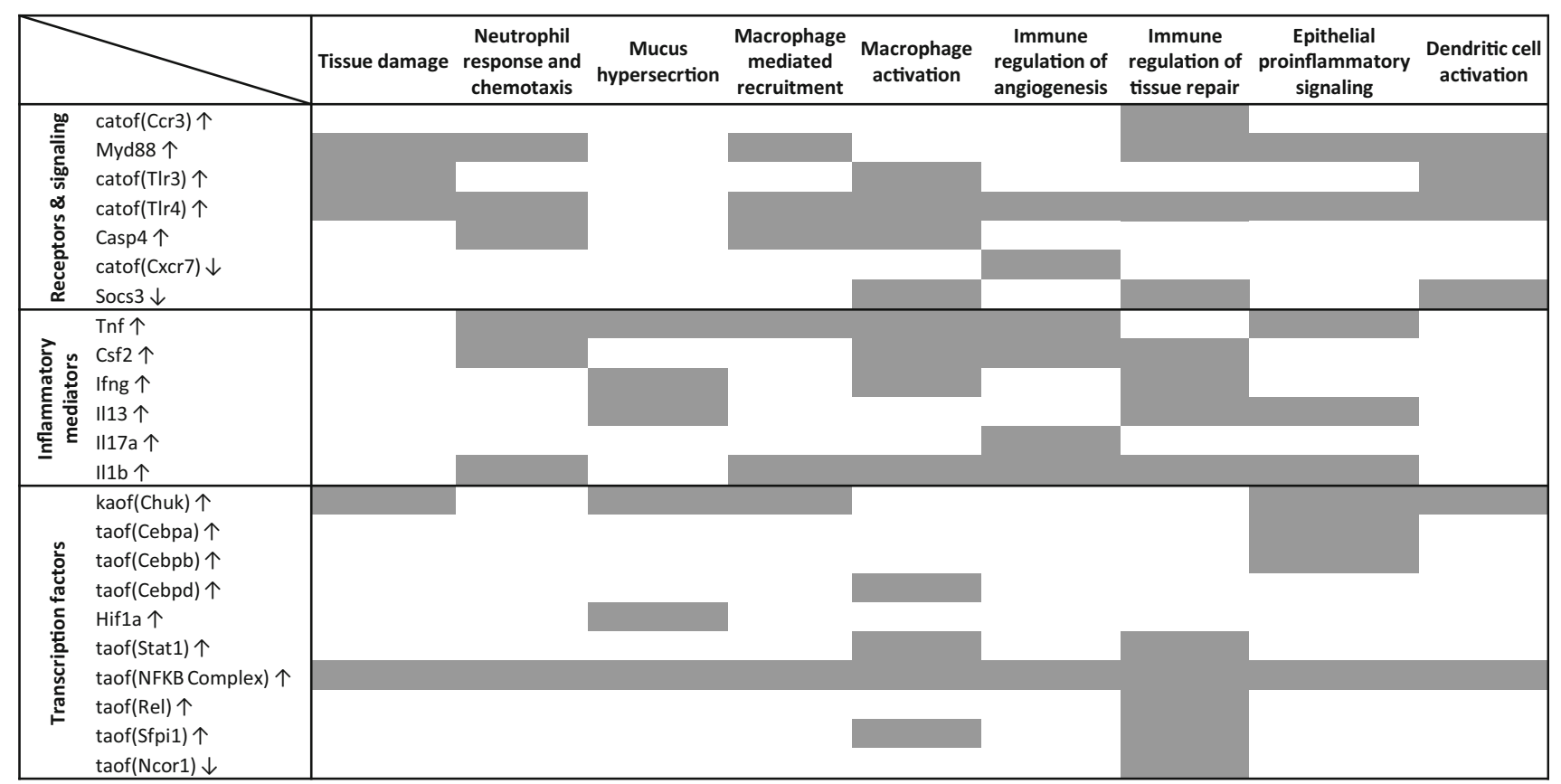

(including increased catalytic activity of TLRs, transcriptional activity of NF- $\mathrm{KB}$, PU.1 and C/EBP, and protein abundance of IFN- $\gamma, \mathrm{CSF} 2$, IL- $1 \beta$, and TNF- $\alpha$ ) remained significantly predicted over the course of CS exposure. Some HYPs, however, such as receptor activity of CCR3 and CCR7, transcriptional activity of C/EBP $\alpha$ and STAT1, and increased protein expression of BRCA1, CASP4, and MyD88 were statistically significant from month 3 onwards of CS exposure. Other HYPs were significant at early time points and not at later time points, namely transcriptional activity of YY1 and protein abundance of IL-20. Phosphatase activity of phosphatase and tensin homolog (PTEN) remained significant with up to 7 months of CS exposure, when compared with fresh air-exposed mice. In the case of suppressor of cytokine signaling (SOCS)-3, ITGB6, and CFTR, predicted decrease in their protein expression persisted over time.

\section{Proteomic analysis of selected HYPs in C57BL/6 mice}

Next, we applied two targeted proteomic approaches to further explore our findings using lungs of C57BL/6 mice exposed to fresh air or 3R4F for up to 7 months. BALF was analyzed with multiplexed bead arrays (Fig. 4a, b), whereas RPPA was applied to lung tissue homogenates from a follow-up study with the same design (Fig. 4c). For RCR predictions reflecting inflammatory mediator protein abundance, we confirmed that BALF levels of TNF- $\alpha$, Il-
$1 \beta$, CSF2 (Fig. 4a), and other "non-HYP" inflammatory mediators including several interleukins, myeloperoxidase (MPO), and matrix-metalloproteinase-9 (MMP-9) (Fig. 4b) were increased upon CS exposure. Protein abundances particularly related to six transcriptional activity-type HYPs were analyzed in lung homogenates by measuring increased protein abundance and phosphorylation levels (Fig. 4c). We applied this approach based on the assumption that regulatory activity (such as DNA-binding ability) of a TF strongly depends on its protein abundance [40, 41]. We observed increased protein levels of BRCA1, C/EBP $\alpha$, C/EBP $\beta$, PU.1, and STAT1, thereby confirming the computationally predicted protein candidates; however, we did not detect increased tyrosine (Tyr705) phosphorylation levels of STAT1 that would further indicate its transcriptional activation. In contrast to RCR predictions, SOCS3 protein expression was increased, whereas MyD88 and ITGB6 protein abundances were not affected by CS exposure (Fig. 4c).

\section{Discussion}

In this study, we employed RCR on whole-genome transcriptomic data sets to computationally predict molecular mechanisms associated with the development of an emphysematous phenotype in mouse models of disease. We predicted 39 HYPs that may represent molecular mechanisms associated with the development of CS-induced 
Fig. 3 Time course of the occurrence of common HYPs in C57BL/6 mice exposed to cigarette smoke (3R4F) for up to 7 months. Results are shown as hierarchically clustered color-coded heatmap according to HYP concordance and richness (3R4F vs. sham comparison is shown). Yelloworange to blue gradient indicates predicted increase and decrease in abundance or activity of HYPs. Catof, catalytic activity of; kaof, kinase activity of; taof, transcriptional activity of; paof, phosphatase activity of; gtpof, GTP-binding activity of. Note: For an easier tracking of the common HYPs from the strain comparison (Fig. 2) and from the temporal development in one strain (Fig. 3), a side-byside comparison in alphabetical order of all HYPs from both heatmaps has been provided in Supplementary Figure 1 (color figure online)

\begin{tabular}{|c|c|c|c|c|c|}
\hline Fig. 3 Time course of the & 6.3e-02 & $1.90-03$ & $0.8 \mathrm{e}-04$ & $2.8 e-04$ & catof(Ccr3) \\
\hline occurrence of common HYPs in & $1.8 e-01$ & $1.7 \mathrm{e}-02$ & $1.5 e-04$ & $3.8 e-04$ & Brca1 \\
\hline C57BL/6 mice exposed to & $1.5 e-02$ & 3.1e-02 & $7.8 e-03$ & $3.5 e-02$ & kaof(Chuk) \\
\hline cigarette smoke ( $3 \mathrm{R} 4 \mathrm{~F})$ for un & $1.5 e-02$ & $2.2 \mathrm{e}-02$ & $1.2 \mathrm{e}-02$ & $1.5 \mathrm{e}-01$ & $\|12 a:\| 12 b$ \\
\hline the & $9.5 \mathrm{e}-03$ & $1.0 e-01$ & $1.1 e-02$ & $1.00-01$ & taof(Cebpb) \\
\hline to 7 montns. Results are snown & $6.3 e-02$ & $3.80-03$ & $1.1 e-02$ & $3.5 \mathrm{e}-02$ & taof(Stat1) \\
\hline as hierarchically clustered & $5.5 e-02$ & $1.1 e-02$ & $1.1 e-02$ & $4.6 e-02$ & Casp4 \\
\hline color-coded heatmap according & $6.3 e-02$ & $1.5 e-02$ & $1.5 e-02$ & $1.5 e-02$ & Myd88 \\
\hline to HYP concordance and & $1.8 \mathrm{e}-02$ & 2.1e-02 & $8.5 \mathrm{e}-02$ & $7.6 e-02$ & 1120 \\
\hline richness (3R4F vs. sham & $5.8 e-02$ & $1.4 e-01$ & $6.8 \mathrm{e}-03$ & $2.3 e-02$ & taof(Cebpa) \\
\hline comparison is shown) Yellow- & $1.9 e-03$ & $1.3 e-01$ & $6.5 \mathrm{e}-03$ & 1. $1 e-02$ & taof(Rel) \\
\hline comparson is snown). rellow- & $7.8 e-04$ & $1.4 e-02$ & $1.7 e-04$ & $1.8 e-04$ & Ifng \\
\hline orange to blue gradient & $2.5 \mathrm{e}-0.4$ & 6.3e-03 & $2.5 e-04$ & 1.1e-04 & Hif1a \\
\hline indicates predicted increase and & $3.0 e-05$ & 2.1e-03 & $4.9 e-04$ & $6.5 \mathrm{e}-03$ & $1117 a$ \\
\hline decrease in abundance or & 6.2e-05 & $2.5 e-04$ & $3.8 \mathrm{e}-08$ & $6.2 e-05$ & taof(Cebpd) \\
\hline activity of HYPs. Catof, & $3.0 \mathrm{e}-05$ & $1.4 e-04$ & $7.6 \mathrm{e}-06$ & $2.5 \mathrm{e}-0.4$ & II17f \\
\hline catalytic activity of: kaof, & $1.9 e-03$ & $3.0 e-05$ & $7.6 \mathrm{e}-06$ & $1.1 e-04$ & Gfap \\
\hline kingse & $2.4 e-07$ & $2.8 e-08$ & $1.4 \mathrm{e}-02$ & $2.7 e-01$ & taof(Yy1) \\
\hline Kinase activity of; taol, & $1.2 e-08$ & $1.2 \mathrm{e}-05$ & $7.90-07$ & 2. $1 e-08$ & $\| 1 \mathrm{~b}$ \\
\hline transcriptional activity of; paof, & $2.4 e-07$ & $2.5 e-07$ & $3.8 \mathrm{e}-\infty$ & $7.6 e-08$ & Foxm1 \\
\hline phosphatase activity of; gtpof, & $5.5 \mathrm{e}-06$ & 2.1e-07 & $1.1 \mathrm{e}-07$ & $1.3 e-06$ & Csf2 \\
\hline GTP-binding activity of. Note: & $7.4 e-08$ & $1.1 \mathrm{e}-08$ & $4.1 e-07$ & $3.2 \mathrm{e}-05$ & $\| 13$ \\
\hline For an easier tracking of the & $3.0 e-07$ & $8.1 e-08$ & $1.2 e-00$ & $2.7 e-07$ & taof(Sfpi1) \\
\hline common HYPs from the strain & $2.8 e-06$ & $6.2 e-08$ & $2.2 e-12$ & $1.5 \mathrm{e}-09$ & IFNalpha Family Mm \\
\hline Cominton & $2.8 e-00$ & $8.7 e-08$ & $24 \mathrm{e}-00$ & $2.8 e-10$ & taof(NFKB Complex Mm) \\
\hline comparison (Fig. 2) and from & 3.1e-13 & $6.8 \mathrm{e}-10$ & $5.0 e-18$ & $2.5 \mathrm{e}-12$ & catof(TIr4) \\
\hline the temporal development in & 1.1e-13 & $1.2 \mathrm{e}-00$ & 4. $6 e-19$ & $1.6 e-13$ & catof(TIr3) \\
\hline one strain (Fig. 3), a side-by- & $9.3 e-14$ & $4.3 e-14$ & $3.0 e-17$ & $3.5 \mathrm{e}-15$ & Tnf \\
\hline side comparison in alphabetical & $6.2 \mathrm{e}-05$ & $3.8 e-06$ & $4.8 e-07$ & $1.00-06$ & Socs 3 \\
\hline order of all HYPs from both & $3.8 \mathrm{e}-05$ & $2.00-00$ & $1.5 \mathrm{e}-06$ & $5.2 \mathrm{e}-08$ & $\operatorname{ltg} b 6$ \\
\hline Order of all HYPS Irom ootn & $1.8 e-08$ & $2.5 \mathrm{e}-07$ & $1.2 e-07$ & $7.6 e-08$ & taof(Ncor 1$)$ \\
\hline neatmaps nas been provided in & $4.0 e-07$ & 8.1e-07 & $3.5 \mathrm{e}-10$ & $1.5 \mathrm{e}-08$ & Cftr \\
\hline Supplementary Figure 1 (color & $3.5 e-11$ & $1.3 e-07$ & 6.3e-06 & $1.8 e-04$ & paof(Pten) \\
\hline figure online) & $1.8 e-02$ & $6.5 e-03$ & $6.3 e-03$ & $6.5 \mathrm{e}-03$ & gtpof(Gna15) \\
\hline & 1.1e-02 & $1.1 e-02$ & $3.8 \mathrm{e}-03$ & $1.3 e-03$ & Mat1a \\
\hline & 2.5e-01 & $6.3 e-02$ & $7.8 \mathrm{e}-03$ & $3.00-03$ & Adnp \\
\hline & $3.5 \mathrm{e}-02$ & $3.2 \mathrm{e}-02$ & $3.8 \mathrm{e}-03$ & $3.0 \mathrm{e}-05$ & taof(Mkl1) \\
\hline & $7.8 e-03$ & 2. $1 \mathrm{e}-03$ & $1.0 e-05$ & $1.4 e-04$ & Dmd \\
\hline & 3.1e-02 & 1.2e-0. & $4.8 e-04$ & $8.00-02$ & catof(Cxcr7) \\
\hline & $\leftarrow$ & $m$ & $\mathbf{0}$ & $\Lambda$ & \\
\hline
\end{tabular}

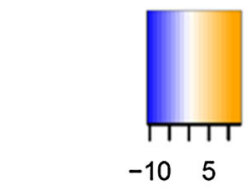

minus $\log _{10}$ (concordance $\mathrm{P}$ value) multiplied by the sign of the concordance score emphysema. These HYPs were conserved across five susceptible mouse models (C57BL/6, ApoE ${ }^{-/-}, \mathrm{A} / \mathrm{J}, \mathrm{CD} 1$, and $\mathrm{Nrf} 2^{-/-}$), suggesting that a core set of biological features may be closely related to emphysema development in a mouse model and may potentially be translatable to human disease. Encouragingly, we verified various wellknown mechanistic changes associated with emphysema development, such as NF- $\kappa \mathrm{B}$ signaling and TLR4 signaling, as well as increased levels of TNF- $\alpha, \mathrm{CSF} 2$, and nonpredicted but related interleukins, MPO, and MMP-9 by means of proteomic analysis. Even more importantly, we identified several novel molecular mechanisms, such as increased transcriptional activity of PU.1, STAT1, C/EBP, FOXM1, and YY1, decreased activity of N-COR1, and reduced protein abundance of ITGB6 and CFTR which have been implicated in disease progression but have not been comprehensively studied in this context, and can be investigated further by targeted experiments. Of note, a large proportion of the HYPs were related to inflammatory processes as outlined in Fig. 5, consistent with the current general concept that an abnormal inflammatory response is a crucial pathological mechanism in the development of CS-induced emphysema [42-44].

\section{Transcription factors}

Transcriptional regulators of inflammatory genes including those related to cytokines, adhesion molecules, enzymes and receptors, is part of the molecular signaling that drives the development and progression of lung pathologies such as asthma and COPD [45, 46]. Therefore, not surprisingly, we predicted increased activation of TFs with well-known roles in emphysema development, such as $\mathrm{NF}-\kappa \mathrm{B}[10,45$, 47-52], but we also revealed TFs with less described or unknown roles in the etiology of emphysema.

For instance, we predicted increased transcriptional activity of C/EBP family members $(\alpha, \beta$, and $\delta$ ) and detected increased abundance (which may be consistent with an effective increase in transcriptional activity) of $\mathrm{C} / \mathrm{EBP} \alpha$ and $\beta$ proteins following smoke exposure. The $\mathrm{C} / \mathrm{EBP}$ family members are key transcriptional regulators of cell differentiation, proliferation, apoptosis, and inflammatory responses [53-55]. Although the binding activity of $\mathrm{C} / \mathrm{EBP} \beta$, and to a lesser extent of $\mathrm{C} / \mathrm{EBP} \alpha$, was enhanced in smokers compared with never-smokers, their role in emphysema remains undefined. It has been hypothesized that $\mathrm{CS}$-increased $\mathrm{C} / \mathrm{EBP}$ activity serves as a protective 


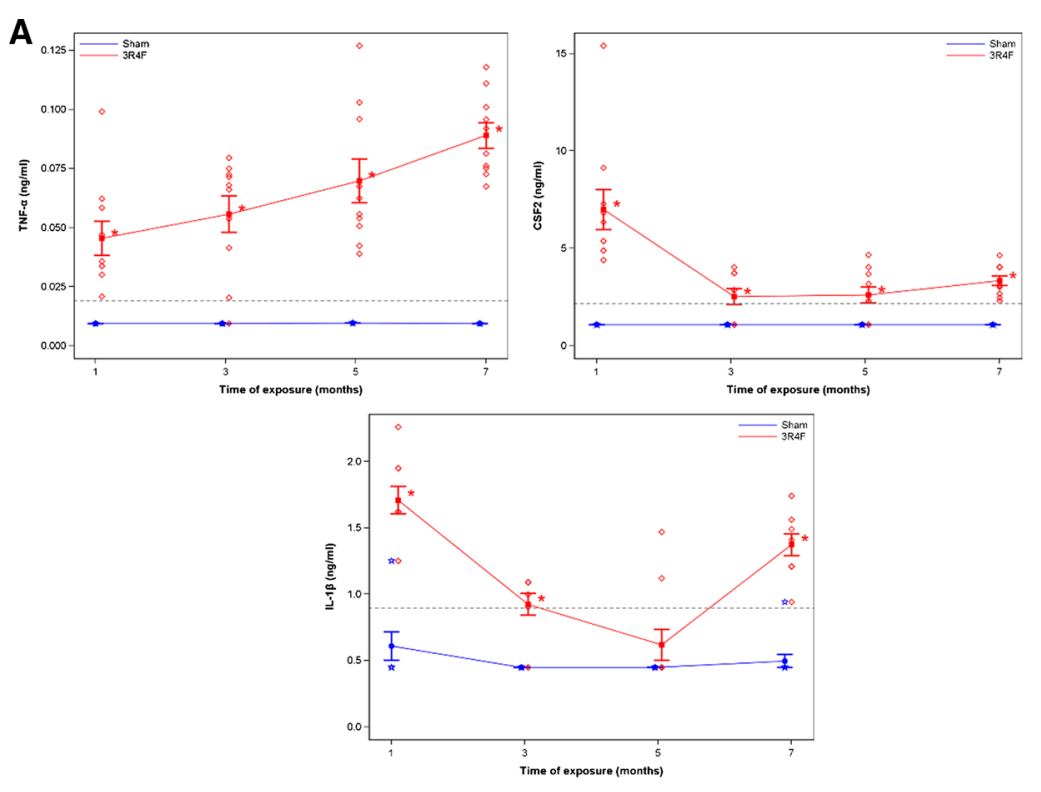

B

C

\begin{tabular}{|c|c|c|c|c|c|}
\hline $\mathrm{BRCA} 1-$ & 1.63 & 1.95 & 1.53 & 1.86 & 1.68 \\
\hline PU.1 - & 1.58 & 1.49 & 1.65 & 1.63 & 1.68 \\
\hline $\mathrm{C} / \mathrm{EBPa}-$ & 1.60 & 1.80 & 1.44 & 2.24 & 1.67 \\
\hline $\mathrm{C} / \mathrm{EBP} \beta-$ & 1.49 & 1.65 & 1.45 & 2.11 & 1.68 \\
\hline p-STAT1 - & 1.05 & 1.11 & 1.02 & 1.14 & 1.08 \\
\hline STAT1 - & 1.35 & 1.45 & 1.57 & 1.51 & 1.59 \\
\hline $\operatorname{socs} 3-$ & 1.27 & 1.68 & 1.44 & 1.41 & 1.51 \\
\hline MyD88 - & 1.09 & 1.02 & 1.02 & 1.05 & 0.96 \\
\hline ITGB6 - & 0.85 & 1.11 & 0.87 & 1.04 & 1.08 \\
\hline & 1 & 1 & 1 & 1 & $\mathrm{~T}$ \\
\hline & 1 & 3 & 4 & 5 & 7 \\
\hline & \multicolumn{5}{|c|}{ Exposure time (Month) } \\
\hline & & \multicolumn{4}{|c|}{ 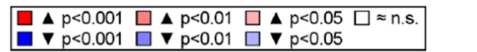 } \\
\hline
\end{tabular}

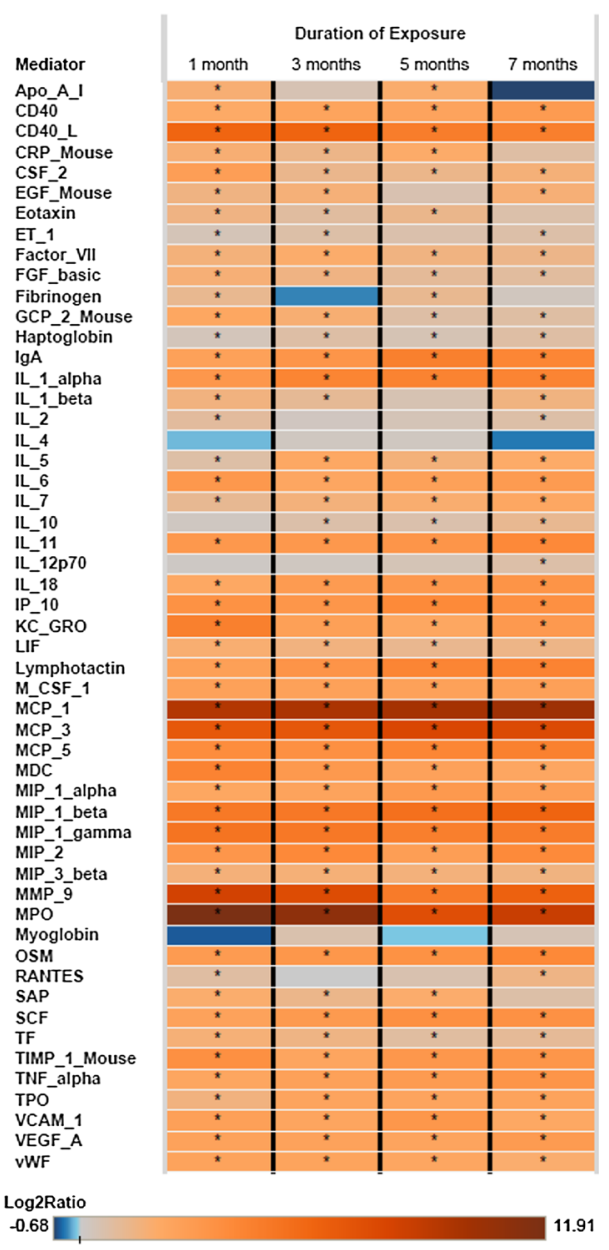

Fig. 4 Proteomic analysis of selected HYPs in C57BL/6 mice exposed to fresh air (sham) or cigarette smoke (3R4F) for up to 7 months. C57BL/6 mice were exposed as described in "Materials and methods" and killed 18-24 h after the last exposure. (a) Levels of BALF inflammatory mediators were measured using multiplexed bead array as described in "Materials and methods". Values of selected inflammatory mediators are presented as single measurements and as mean $\pm \mathrm{SD}\left(n=8-10\right.$ per group). ${ }^{*} P \leq 0.05$; (3R $4 \mathrm{~F}$ vs. sham). Blue stars and lines sham; red diamonds and lines 3R4F;

mechanism by stimulating lung epithelial regeneration through promotion of cell proliferation, inhibition of apoptotic signals, and activation of inflammatory genes [53]. In mice, lung epithelial-specific inactivation of $\mathrm{C} / \mathrm{EBP} \beta$ resulted in impaired CS-induced neutrophil recruitment to the lung and compromised induction of neutrophil chemoattractants, but its contribution to emphysema is unclear, in particular because the mRNA levels of $\mathrm{C} / \mathrm{EBP} \beta$ were down-regulated in the airway epithelium of smokers [56], which is difficult to align with the previous findings from the same group that the $\mathrm{C} / \mathrm{EBP}$ binding activities were increased in the lung tissue from healthy gray dotted line limit of detection/quantification (b) Heatmap representation of all regulated inflammatory mediators from the BALF analysis. The color coding indicates the $\log _{2}$ ratio of protein abundance $(3 \mathrm{R} 4 \mathrm{~F}$ vs. sham); $* P \leq 0.05$. (c) Protein abundance in lung homogenates was measured using RPPA as described in "Materials and methods" ( $n=10$ per group). Results are shown as ratios of abundance (3R4F/Sham) and color-coded heatmap reflecting statistical significance (color figure online)

smokers but not from COPD and chronic bronchitis patients [53]. Our results, together with the known role of $\mathrm{C} / \mathrm{EBPs}$ in controlling expression of genes encoding inflammatory cytokines, and proteinases, suggest C/EBP family members as important players in the pathogenesis of emphysema [53, 54, 57].

We also predicted increased activity of PU.1, a TF selectively expressed in hematopoietic tissues, which plays a critical role in development, maturation, and function of lymphoid and myeloid cells such as macrophages [58]. Indeed, PU.1 is required for many functions performed by alveolar macrophages, including phagocytosis, MMP 


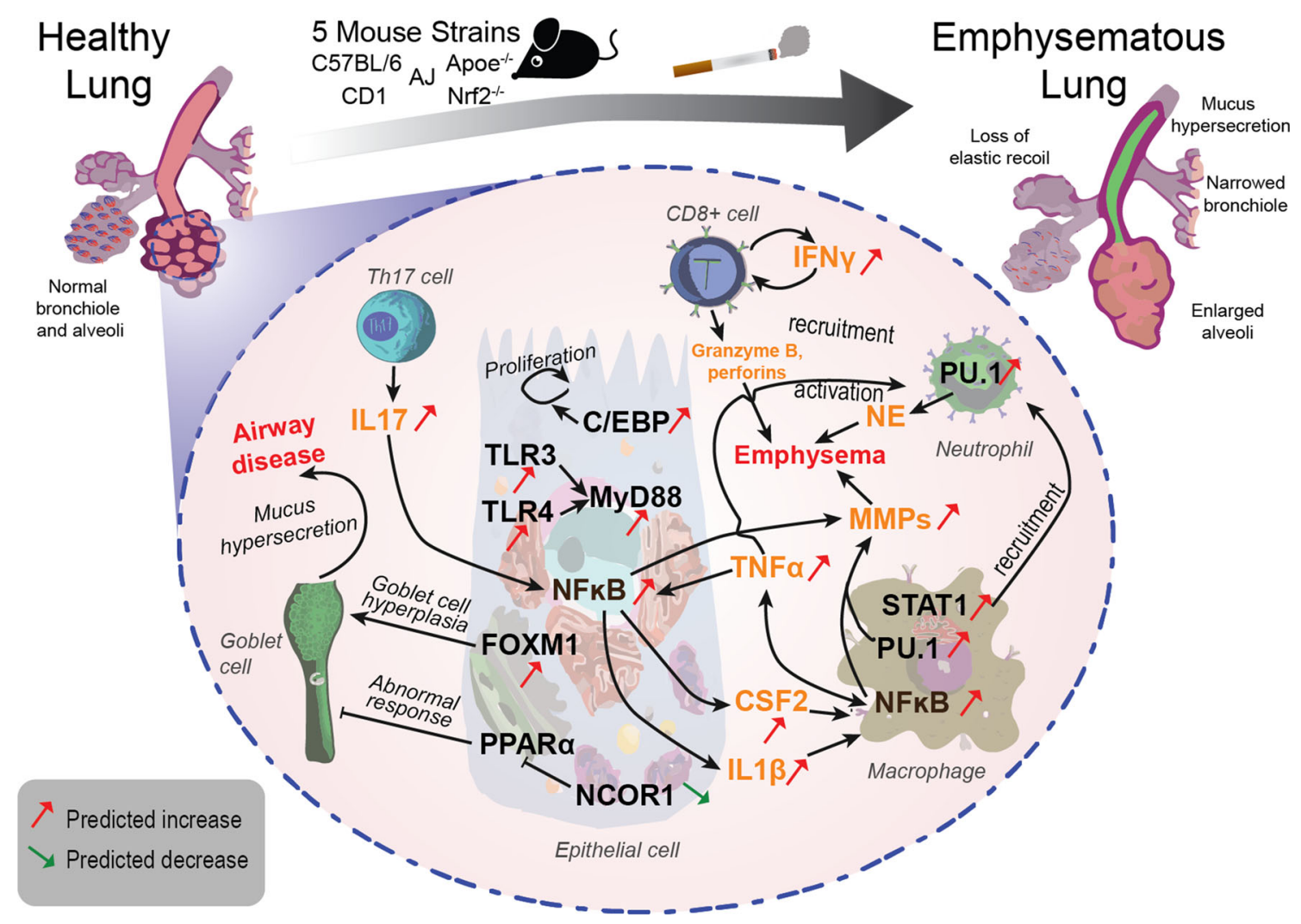

Fig. 5 Possible interrelationships and roles for the identified common mechanisms (HYPs) in five mouse models of emphysema in a framework of classical human COPD mechanisms. The RCRpredicted decreases (green arrows) and increases (red arrows) in transcription factors (black font) and inflammatory mediators (orange font) common to the investigated mouse models have been associated with classical pathways of human COPD pathogenesis (black arrows) as depicted, e.g., in recent reviews [98, 99] and in other relevant articles mentioned in the "Discussion". Central predicted roles for emphysema formation (on the right side) are assigned to the NFKB signaling in epithelial cells and macrophages triggered by, e.g.,
TNF $\alpha$, IL17, or activation of TLR3/4, resulting in the shedding of TNF $\alpha$, CSF2, Illb, and MMPs. The predicted and measured activation of STAT1- and PU.1 would (particularly in macrophages) also be consistent with the recruitment and activation of neutrophils that enhance emphysema by NE production. On the left side of the scheme, the predicted decrease in NCOR1 activity in conjunction with increased transcriptional activity of FOXM1 would be in conformity with goblet cell activation involved in airway disease (which in mouse models is less pronounced than in human COPD patients). For further details, please refer to the "Discussion" (color figure online) expression, reactive oxygen species production, surfactant catabolism, and secretion of pro-inflammatory cytokines [58] and lipoxygenase, which is implicated in asthma, atherosclerosis, and arthritis [59]. In addition, PU.1 has been shown to regulate expression and activity of emphysema-associated proteolytic enzymes such as cathepsin $\mathrm{S}$ and neutrophil elastase (NE) [60,61]. Our results suggest that the activity of PU.1 may play a significant role in the development and progression of emphysema due to its maximal statistical enrichment occurring at month 5 (Fig. 3), corresponding to the time course of increasing emphysematous changes in the C57BL/6 model [62]. Furthermore, its activity is even more pronounced in other mouse strains (e.g. Nrf2 ${ }^{-} I^{-}$) at the month-5 time point, suggesting an even more significant role in the process of emphysema development (Fig. 2).
STAT1 is a known inducer of emphysema-associated processes such as apoptosis and inflammation; however, its precise role in emphysema and COPD development has not been established. Recently it has been demonstrated that STAT1 protein abundance is augmented in emphysematous lungs of $\mathrm{gp} 130^{\mathrm{F} / \mathrm{F}}$ mice, although without significant changes in its tyrosine phosphorylation [63]. In addition, exposure of bronchial cells to CS extracts resulted in increased STAT1 phosphorylation and binding to the promoter regions of intercellular adhesion molecule (ICAM)-1, a mechanism that may contribute to airway neutrophilia and tissue damage [64]. STAT1 phosphorylation levels are increased in sputum from COPD patients, which induces oxidative and nitrosative stress in 16-HBE bronchial epithelial cells [65]. In bronchial biopsies from COPD patients compared to asymptomatic smokers, more 
cells being positive for phosphorylated STAT1 have been observed [66]. Results described here further support a potential role of STAT1 in emphysema development.

We also predicted increased transcriptional activity of FOXM1 which is a member of the forkhead box (Fox) family of TFs that play important roles in cellular proliferation, differentiation, and tumorigenesis [67]. Its role in inflammation has been evaluated using a mouse model of house dust mite allergen-induced allergic asthma. It has been shown that conditional deletion of the Foxml gene from either airway epithelium or myeloid inflammatory cells decreased goblet cell metaplasia, reduced lung inflammation, and decreased airway resistance [68]. Moreover, the amount of FOXM1 protein was increased in bronchiolar epithelium and in inflammatory cells isolated from COPD patients [68], but no further studies were performed to investigate the role of FOXM1 in CS-induced emphysema in mice or humans. For YY1, we also predicted increased transcriptional activity predominantly at the early time points and this effect was diminished at later time points; so far, a role for this transcription factor in COPD has been observed only in COPD-associated skeletal muscle atrophy, but not in lung tissue [69]. No association with COPD has been reported for NCOR1, a co-repressor of PPAR $\delta, \gamma$, and an antagonist of $\beta$-catenin [70], but the known involvement of the Wnt $\beta$-catenin pathway in abnormal airway responses in COPD patients $[71,72]$ and the established protective role of PPAR $\gamma$ activation against COPD [73-75] warrant further investigations related to the predicted activation of NCOR1 in COPD-susceptible mouse models.

\section{Th1/Th2/Th17-type cytokines}

A common characteristic of COPD is progressive lymphocyte infiltration into the small airways and alveolar walls [76, 77]. In mice, CS-exposure induces lung recruitment of $\mathrm{CD}^{+}, \mathrm{CD}^{+}$, and $\mathrm{B}$ cells, enhancing proinflammatory Th1 cytokine production that might significantly contribute to emphysema development [8]. Indeed, deletion of genes encoding the TNF- $\alpha$ receptor or IFN- $\gamma$ protects mice from development of CS-induced emphysema [78, 79], whereas TNF- $\alpha$ or IFN- $\gamma$ overexpression leads to lung emphysema [80-82]. In this regard, using an RCR analysis and proteomic approach, we predicted and/or measured increased protein abundance over time for Th1-associated cytokines such as TNF- $\alpha$, IL-2, and IFN- $\gamma$ in CS-exposed mice. At the same time, we predicted increased protein levels of IL-13, a Th2 cytokine, which may contribute to mucus hypersecretion and chronic bronchitis in smokers and COPD patients [83, 84]. We also measured increased abundance of the Th2 effector cytokines IL-4, 5, 6, and 10. Although the mucus hypersecretion response is not well recapitulated in rodents [83], a direct role of IL-13 in CS-induced emphysema has been demonstrated [60].

A large number of studies have shown that COPD is largely associated with increased Th1 responses; however, recent studies have proposed an important role for Th17 cells in the pathogenesis of COPD [85, 86]. In mice, chronic exposure to CS has been shown to induce lung recruitment of Th17 cells [87]. More recently, Chen et al. [88] demonstrated that mice lacking the IL-17A receptor $\left(I l 17 \mathrm{Ra}^{-/-}\right)$failed to develop emphysema after 6 months of CS exposure. Likewise, IL-17 was essential for elastaseinduced emphysema formation and lung inflammation in C57BL/6 mice [89]. In agreement with these data, we have predicted increased abundance of the two IL-17 family members, IL-17A and IL-17F, in emphysematous lungs, with maximal inferred abundance peaking at the month-5 experimental time point, corresponding to the time course of emphysematous changes and suggesting involvement in the tissue destruction process.

\section{Protease-antiprotease imbalance}

Protease-antiprotease imbalance is regarded as a prevailing mechanism in the development of mouse and human emphysema [90]. Key events leading to lung extracellular matrix degradation during this process involve inflammatory cell recruitment into the lungs and the release of an uncontrolled amount of proteases. Indeed, increased lung concentrations of NE, MMP-1, MMP-9, and MMP-12 have been found in CS-exposed mice and emphysema patients [91], and thus excessive proteolytic activity must be tightly regulated. Morris et al. [92] described an interesting mechanism regulating MMP-12 activity, showing that Itgb6-null mice lacking the $\beta$-subunit of the $\alpha v \beta 6$ integrin, an integrin abundantly expressed by bronchiolar and alveolar epithelial cells, developed spontaneous age-related MMP-12-dependent emphysema. In accordance, we predicted reduced ITGB6 protein abundance as a potential mechanism contributing to CS-induced emphysema; however, the measured ITGB6 protein abundance in lung homogenates did not change as a result of CS exposure. We can speculate that post translational modifications may stabilize the integrin molecules at the sites of cell adhesion and, therefore, a down-regulation of newly synthesized ITGB6 as predicted will not necessarily translate into reduced amounts of total ITGB6 in the tissue; however, further studies are necessary to explore the observed discrepancy.

Our proteomic approach did not confirm RCR predictions for decreased SOCS3 and increased MyD88 protein abundances; however, considering their known role in inflammatory processes these mechanisms are potentially 
active. SOCS3 is an important negative regulator of inflammatory reactions, especially in IL-6-driven pathological conditions [93]. Moreover, mice with hematopoietic cell-specific deletion of the Socs3 gene developed neutrophilia and a variety of inflammatory pathologies [94]. Thus, the predicted decrease of SOCS3 protein may significantly contribute to the observed progression of CS-induced pathologies (e.g. neutrophilia, lung emphysema). We can speculate that RPPA-detected increased SOCS3 protein levels in the whole lung tissue may represent a compensatory mechanism to limit inflammation and/or SOCS3 protein degradation mechanisms can be inhibited by CS. With regard to MyD88, it serves as an essential adaptor protein in TLR and IL1R signaling pathway [95], and MyD88 deficiency leads to spontaneous emphysema [96]. On the other hand, CS-induced neutrophilia was ablated in MyD88-deficient mice [97].

Collectively, the RCR analysis of lung transcriptomic data provides a robust approach for comparing and identifying molecular changes involved in the development of CS-induced emphysema, which was also corroborated by the independently measured protein abundances of selected HYPs. Many of the common mechanistic features identified here are consistent with prevailing theories of disease development in murine models of CS-induced emphysema, as well as in the pathogenesis of human COPD, testifying to the powerful predictive ability of the RCR approach in assessing disease development and progression. The putative correspondence of predicted changes in transcription factor activities and inflammatory mediator abundances with classical mechanisms of COPD pathogenesis [98, 99] has been depicted in Fig. 5. Furthermore, we extended our analysis to identify a series of novel molecular mechanisms with potentially causative roles in emphysema development for further exploration. In conclusion, a systems toxicology approach, including histopathology, transcriptomics, proteomics, and computational hypothesis generation, has been applied to investigate the molecular mechanisms of CS-induced emphysema in a variety of susceptible mouse strains. Clearly, further studies to functionally validate our predictions are needed; however, the results of our meta-analysis open new vistas to obtain more detailed insights into the pathogenic mechanisms of emphysema, and of COPD in general.

Acknowledgments We would like to thank Ignacio Rodriguez Suarez and Matthias Schorp for helpful comments and discussions, Patrice Leroyand Gregory Vuillaume for statistical support, and Sam Ansari for submitting the gene expression data to ArrayExpress (EMTAB-2756).

Conflict of interest The authors and the research described in this paper were supported by Philip Morris International.
Open Access This article is distributed under the terms of the Creative Commons Attribution 4.0 International License (http:// creativecommons.org/licenses/by/4.0/), which permits unrestricted use, distribution, and reproduction in any medium, provided you give appropriate credit to the original author(s) and the source, provide a link to the Creative Commons license, and indicate if changes were made.

\section{References}

1. Snider GL. Nosology for our day: its application to chronic obstructive pulmonary disease. Am J Respir Crit Care Med. 2003;167(5):678-83 (PubMed PMID: 12598211. Epub 2003/02/25. eng).

2. Vestbo J, Hurd SS, Agusti AG, Jones PW, Vogelmeier C, Anzueto A, et al. Global strategy for the diagnosis, management, and prevention of chronic obstructive pulmonary disease: GOLD executive summary. Am J Respir Crit Care Med. 2013;187(4):347-65 (PubMed PMID: 22878278. Epub 2012/08/11. eng).

3. Tuder RM, Yoshida T, Arap W, Pasqualini R, Petrache I. State of the art. Cellular and molecular mechanisms of alveolar destruction in emphysema: an evolutionary perspective. Proc Am Thorac Soc. 2006;3(6):503-10 (PubMed PMID: 16921129. Pubmed Central PMCID: PMC2647641. Epub 2006/08/22. eng).

4. Tuder RM, Petrache I, Elias JA, Voelkel NF, Henson PM. Apoptosis and emphysema: the missing link. Am J Respir Cell Mol Biol. 2003;28(5):551-4 (PubMed PMID: 12707010. Epub 2003/04/23. eng).

5. Boschetto P, Quintavalle S, Miotto D, Lo Cascio N, Zeni E, Mapp CE. Chronic obstructive pulmonary disease (COPD) and occupational exposures. J Occup Med Toxicol. 2006;1:11 (PubMed PMID: 16756686. Pubmed Central PMCID: 1513231. Epub 2006/06/08. eng).

6. Kant S, Gupta B. Role of lifestyle in the development of chronic obstructive pulmonary disease: a review. Lung India Off Organ Indian Chest Soc. 2008;25(2):95-101 (PubMed PMID: 20165658. Pubmed Central PMCID: 2822328. Epub 2008/04/ 01. eng).

7. Berndt A, Leme AS, Shapiro SD. Emerging genetics of COPD. EMBO Mol Med. 2012;4(11):1144-55 (PubMed PMID: 23090857. Pubmed Central PMCID: 3494872. Epub 2012/10/ 24. Eng).

8. Guerassimov A, Hoshino Y, Takubo Y, Turcotte A, Yamamoto $\mathrm{M}$, Ghezzo H, et al. The development of emphysema in cigarette smoke-exposed mice is strain dependent. Am J Respir Crit Care Med. 2004;170(9):974-80 (PubMed PMID: 15282203. Epub 2004/07/30. eng).

9. Tsuji H, Fujimoto H, Matsuura D, Nishino T, Lee KM, Renne R, et al. Comparison of mouse strains and exposure conditions in acute cigarette smoke inhalation studies. Inhal Toxicol. 2011;23(10):602-15 (PubMed PMID: 21864220. Epub 2011/08/26. Eng).

10. Yao H, Edirisinghe I, Rajendrasozhan S, Yang SR, Caito S, Adenuga D, et al. Cigarette smoke-mediated inflammatory and oxidative responses are strain-dependent in mice. Am J Physiol Lung Cell Mol Physiol. 2008;294(6):L1174-86 (PubMed PMID: 18375740. Epub 2008/04/01. eng).

11. Churg A, Sin DD, Wright JL. Everything prevents emphysema: are animal models of cigarette smoke-induced chronic obstructive pulmonary disease any use? Am J Respir Cell Mol Biol. 
2011;45(6):1111-5 (PubMed PMID: 21685155. Epub 2011/06/ 21. Eng).

12. Onnervik PO, Lindahl M, Svitacheva N, Stampfli M, Thim K, Smailagic A, et al. The role of the CCR1 receptor in the inflammatory response to tobacco smoke in a mouse model. Inflamm Res. 2010;59(10):817-25 (PubMed PMID: 20387089. Pubmed Central PMCID: 2933852. Epub 2010/04/14. eng).

13. Bracke KR, D'Hulst AI, Maes T, Demedts IK, Moerloose KB, Kuziel WA, et al. Cigarette smoke-induced pulmonary inflammation, but not airway remodelling, is attenuated in chemokine receptor 5-deficient mice. Clin Exp Allergy. 2007;37(10):1467-79 (PubMed PMID: 17883726. Epub 2007/09/22. Eng).

14. Bracke KR, D'Hulst AI, Maes T, Moerloose KB, Demedts IK, Lebecque $S$, et al. Cigarette smoke-induced pulmonary inflammation and emphysema are attenuated in CCR6-deficient mice. J Immunol. 2006;177(7):4350-9 (PubMed PMID: 16982869. Epub 2006/09/20. Eng).

15. Churg A, Wang R, Wang X, Onnervik PO, Thim K, Wright JL. Effect of an MMP-9/MMP-12 inhibitor on smoke-induced emphysema and airway remodelling in guinea pigs. Thorax. 2007;62(8):706-13 (PubMed PMID: 17311841. Pubmed Central PMCID: 2117295. Epub 2007/02/22. eng).

16. Hoshino T, Kato S, Oka N, Imaoka H, Kinoshita T, Takei S, et al. Pulmonary inflammation and emphysema: role of the cytokines IL-18 and IL-13. Am J Respir Crit Care Med. 2007;176(1):49-62 (PubMed PMID: 17400729. Epub 2007/04/03. eng).

17. Lappalainen U, Whitsett JA, Wert SE, Tichelaar JW, Bry K. Interleukin-1beta causes pulmonary inflammation, emphysema, and airway remodeling in the adult murine lung. Am J Respir Cell Mol Biol. 2005;32(4):311-8 (PubMed PMID: 15668323. Epub 2005/01/26. eng).

18. McMillan DH, Baglole CJ, Thatcher TH, Maggirwar S, Sime PJ, Phipps RP. Lung-targeted overexpression of the NF-kappaB member RelB inhibits cigarette smoke-induced inflammation. Am J Pathol. 2011;179(1):125-33 (PubMed PMID: 21703398. Pubmed Central PMCID: 3123857. Epub 2011/06/28. eng).

19. Rangasamy T, Cho CY, Thimmulappa RK, Zhen L, Srisuma SS, Kensler TW, et al. Genetic ablation of Nrf2 enhances susceptibility to cigarette smoke-induced emphysema in mice. J Clin Invest. 2004;114(9):1248-59 (PubMed PMID: 15520857. Pubmed Central PMCID: 524225. Epub 2004/11/03. eng).

20. Reddy NM, Vegiraju S, Irving A, Paun BC, Luzina IG, Atamas SP, et al. Targeted deletion of Jun/AP-1 in alveolar epithelial cells causes progressive emphysema and worsens cigarette smoke-induced lung inflammation. Am J Pathol. 2012;180(2):562-74 (PubMed PMID: 22265050. Pubmed Central PMCID: 3349866. Epub 2012/01/24. eng).

21. Cavarra E, Fardin P, Fineschi S, Ricciardi A, De Cunto G, Sallustio F, et al. Early response of gene clusters is associated with mouse lung resistance or sensitivity to cigarette smoke. Am J Physiolo Lung Cell Mol Physiol. 2009;296(3):L418-29 (PubMed PMID: 19118092. Epub 2009/01/02. eng).

22. Meng QR, Gideon KM, Harbo SJ, Renne RA, Lee MK, Brys AM, et al. Gene expression profiling in lung tissues from mice exposed to cigarette smoke, lipopolysaccharide, or smoke plus lipopolysaccharide by inhalation. Inhal Toxicol. 2006;18(8):555-68 (PubMed PMID: 16717027. Epub 2006/05/ 24. eng).

23. Stevenson CS, Docx C, Webster R, Battram C, Hynx D, Giddings $\mathrm{J}$, et al. Comprehensive gene expression profiling of rat lung reveals distinct acute and chronic responses to cigarette smoke inhalation. Am J Physiol Lung Cell Mol Physiol. 2007;293(5):L1183-93 (PubMed PMID: 17720875. Epub 2007/08/28. eng).
24. Morissette MC, Lamontagne M, Berube JC, Gaschler G, Williams A, Yauk C, et al. Impact of cigarette smoke on the human and mouse lungs: a gene-expression comparison study. PLoS One. 2014;9(3):e92498 (PubMed PMID: 24663285. Pubmed Central PMCID: 3963906. Epub 2014/03/26. eng).

25. Xiang Y, Kogel U, Gebel S, Peck MJ, Peitsch MC, Akmaev VR, et al. Discovery of Emphysema Relevant Molecular Networks from an A/J Mouse Inhalation Study Using Reverse Engineering and Forward Simulation (REFS). Gene regulation and systems biology. 2014;8:45-61 (PubMed PMID: 24596455. Pubmed Central PMCID: PMC3937248. Epub 2014/03/07. eng).

26. Catlett NL, Bargnesi AJ, Ungerer S, Seagaran T, Ladd W, Elliston $\mathrm{KO}$, et al. Reverse causal reasoning: applying qualitative causal knowledge to the interpretation of high-throughput data. BMC bioinformatics. 2013;14(1):340 (PubMed PMID: 24266983. Epub 2013/11/26. Eng).

27. Hoeng J, Talikka M, Martin F, Sewer A, Yang X, Iskandar A, et al. Case study: the role of mechanistic network models in systems toxicology. Drug Discov Today. 2013;19(2):183-92 (PubMed PMID: 23933191. Epub 2013/08/13. Eng).

28. Boue S, De Leon H, Schlage WK, Peck MJ, Weiler H, Berges A, et al. Cigarette smoke induces molecular responses in respiratory tissues of ApoE mice that are progressively deactivated upon cessation. Toxicology. 2013;314(1):112-24 (PubMed PMID: 24096154. Epub 2013/10/08. Eng).

29. Gebel S, Diehl S, Pype J, Friedrichs B, Weiler H, Schuller J, et al. The transcriptome of Nrf2-/- mice provides evidence for impaired cell cycle progression in the development of cigarette smokeinduced emphysematous changes. Toxicol Sci off J Soc Toxicol. 2010;115(1):238-52 (PubMed PMID: 20133372. Epub 2010/02/06. eng).

30. Boue S, Tarasov K, Janis M, Lebrun S, Hurme R, Schlage W, et al. Modulation of atherogenic lipidome by cigarette smoke in apolipoprotein E-deficient mice. Atherosclerosis. 2012;225(2):328-34 (PubMed PMID: 23102783. Epub 2012/10/30. Eng).

31. von Holt K, Lebrun S, Stinn W, Conroy L, Wallerath T, Schleef R. Progression of atherosclerosis in the Apo E-/- model: 12-month exposure to cigarette mainstream smoke combined with highcholesterol/fat diet. Atherosclerosis. 2009;205(1):135-43.

32. Hoeng J, Talikka M, Martin F, Sewer A, Yang X, Iskandar A, et al. Case study: the role of mechanistic network models in systems toxicology. Drug Discov Today. 2013;19(2):183-92 (PubMed PMID: 23933191. Epub 2013/08/13. Eng).

33. Kogel U, Schlage WK, Martin F, Xiang Y, Ansari S, Leroy P, et al. A 28-day rat inhalation study with an integrated molecular toxicology endpoint demonstrates reduced exposure effects for a prototypic modified risk tobacco product compared with conventional cigarettes. Food Chem Toxicol Int J Publ Br Ind Biol Res Assoc. 2014;68:204-17 (PubMed PMID: 24632068. Eng).

34. Gebel S, Diehl S, Pype J, Friedrichs B, Weiler H, Schuller J, et al. The transcriptome of Nrf2-/- mice provides evidence for impaired cell cycle progression in the development of cigarette smokeinduced emphysematous changes. Toxicol Sci. 2010;115(1):238-52.

35. Agnew BJ, Murray D, Patton WF. A rapid solid-phase fluorescence-based protein assay for quantitation of protein electrophoresis samples containing detergents, chaotropes, dyes, and reducing agents. Electrophoresis. 2004;25(15):2478-85 (PubMed PMID: 15300765. Epub 2004/08/10. eng).

36. Pawlak M, Schick E, Bopp MA, Schneider MJ, Oroszlan P, Ehrat M. Zeptosens' protein microarrays: a novel high performance microarray platform for low abundance protein analysis. Proteomics. 2002;2(4):383-93 (PubMed PMID: 12164697. Epub 2002/08/08. Eng). 
37. Westra JW, Schlage WK, Hengstermann A, Gebel S, Mathis C, Thomson $\mathrm{T}$, et al. A modular cell-type focused inflammatory process network model for non-diseased pulmonary tissue. Bioinform Biol Insights. 2013;20(7):167-92.

38. Park JS, Schlage WK, Frushour BP, Talikka M, Toedter G, Gebel S, Deehan R, Veljkovic E, Westra JW, Peck MJ, Boue S, Kogel U, Gonzalez-Suarez I, Hengstermann A, Peitsch MC, Hoeng J. Construction of a Computable Network Model of Tissue Repair and Angiogenesis in the Lung. J Clinic Toxicol 2013, S12-002. 2013.

39. Beckett EL, Stevens RL, Jarnicki AG, Kim RY, Hanish I, Hansbro NG, et al. A new short-term mouse model of chronic obstructive pulmonary disease identifies a role for mast cell tryptase in pathogenesis. J Allergy Clin Immunol. 2013;131(3):752-62 (PubMed PMID: 23380220. Epub 2013/02/06. eng).

40. Rosenbauer F, Tenen DG. Transcription factors in myeloid development: balancing differentiation with transformation. Nat Rev Immunol. 2007;7(2):105-17 (PubMed PMID: 17259967. Epub 2007/01/30. eng).

41. Simicevic J, Schmid AW, Gilardoni PA, Zoller B, Raghav SK, Krier I, et al. Absolute quantification of transcription factors during cellular differentiation using multiplexed targeted proteomics. Nat Methods. 2013;10(6):570-6 (PubMed PMID: 23584187. Epub 2013/04/16. eng).

42. Cosio MG, Saetta M, Agusti A. Immunologic aspects of chronic obstructive pulmonary disease. N Engl J Med. 2009;360(23):2445-54 (PubMed PMID: 19494220. Epub 2009/06/06. eng).

43. Finkelstein R, Fraser RS, Ghezzo H, Cosio MG. Alveolar inflammation and its relation to emphysema in smokers. Am J Respir Crit Care Med. 1995;152(5 Pt 1):1666-72 (PubMed PMID: 7582312. Epub 1995/11/01. eng).

44. Tetley TD. Inflammatory cells and chronic obstructive pulmonary disease. Curr Drug Targets Inflamm Allergy. 2005;4(6):607-18 (PubMed PMID: 17305517. Epub 2007/02/20. eng).

45. Caramori G, Casolari P, Adcock I. Role of transcription factors in the pathogenesis of asthma and COPD. Cell Commun Adhes. 2013;20(1-2):21-40 (PubMed PMID: 23472830. Epub 2013/03/12. eng).

46. Rahman I, MacNee W. Role of transcription factors in inflammatory lung diseases. Thorax. 1998;53(7):601-12 (PubMed PMID: 9797762. Pubmed Central PMCID: 1745272. Epub 1998/11/03. eng).

47. Li YT, He B, Wang YZ, Wang J. Effects of intratracheal administration of nuclear factor-kappaB decoy oligodeoxynucleotides on long-term cigarette smoke-induced lung inflammation and pathology in mice. Respir Res. 2009;10:79 (PubMed PMID: 19706153. Pubmed Central PMCID: 2751757. Epub 2009/08/27. Eng).

48. Vlahos R, Bozinovski S, Jones JE, Powell J, Gras J, Lilja A, et al. Differential protease, innate immunity, and NF-kappaB induction profiles during lung inflammation induced by subchronic cigarette smoke exposure in mice. American journal of physiology Lung cellular and molecular physiology. 2006;290(5):L931-45 (PubMed PMID: 16361358. Epub 2005/12/20. eng).

49. Marwick JA, Kirkham PA, Stevenson CS, Danahay H, Giddings J, Butler K, et al. Cigarette smoke alters chromatin remodeling and induces proinflammatory genes in rat lungs. American journal of respiratory cell and molecular biology. 2004;31(6):633-42 (PubMed PMID: 15333327. Epub 2004/08/31. eng).

50. Rajendrasozhan S, Hwang JW, Yao H, Kishore N, Rahman I. Anti-inflammatory effect of a selective IkappaB kinase-beta inhibitor in rat lung in response to LPS and cigarette smoke. Pulm Pharmacol Ther. 2010;23(3):172-81 (PubMed PMID: 20080200. Pubmed Central PMCID: 2850968. Epub 2010/01/ 19. eng).
51. Di Stefano A, Caramori G, Oates T, Capelli A, Lusuardi M, Gnemmi I, et al. Increased expression of nuclear factor-kappaB in bronchial biopsies from smokers and patients with COPD. Eur Respir J Off J Eur Soc Clin Respir Physiol. 2002;20(3):556-63 (PubMed PMID: 12358328. Epub 2002/10/03. eng).

52. Szulakowski P, Crowther AJ, Jimenez LA, Donaldson K, Mayer $\mathrm{R}$, Leonard TB, et al. The effect of smoking on the transcriptional regulation of lung inflammation in patients with chronic obstructive pulmonary disease. Am J Respir Crit Care Med. 2006;174(1):41-50 (PubMed PMID: 16574938. Epub 2006/04/ 01. eng).

53. Didon L, Qvarfordt I, Andersson O, Nord M, Riise GC. Decreased CCAAT/enhancer binding protein transcription factor activity in chronic bronchitis and COPD. Chest. 2005;127(4):1341-6 (PubMed PMID: 15821213. Epub 2005/04/12. eng).

54. Miglino N, Roth M, Tamm M, Borger P. Asthma and COPDthe C/EBP connection. The open respiratory medicine journal. 2012;6:1-13 (PubMed PMID: 22715349. Pubmed Central PMCID: PMC3377872. Epub 2012/06/21. eng).

55. Cassel TN, Nord M. C/EBP transcription factors in the lung epithelium. American journal of physiology Lung cellular and molecular physiology. 2003;285(4):L773-81 (PubMed PMID: 12959923. Epub 2003/09/10. eng).

56. Didon L, Barton JL, Roos AB, Gaschler GJ, Bauer CM, Berg T, et al. Lung epithelial CCAAT/enhancer-binding protein-beta is necessary for the integrity of inflammatory responses to cigarette smoke. Am J Respir Crit Care Med. 2011;184(2):233-42 (PubMed PMID: 21562127. Epub 2011/05/13. eng).

57. Poli V. The role of C/EBP isoforms in the control of inflammatory and native immunity functions. $\mathrm{J}$ Biol Chem. 1998;273(45):29279-82 (PubMed PMID: 9792624. Epub 1998/10/29. eng).

58. Shibata Y, Berclaz PY, Chroneos ZC, Yoshida M, Whitsett JA, Trapnell BC. GM-CSF regulates alveolar macrophage differentiation and innate immunity in the lung through PU.1. Immunity. 2001;15(4):557-67 (PubMed PMID: 11672538. Epub 2001/10/ 24. eng).

59. Wittwer J, Marti-Jaun J, Hersberger M. Functional polymorphism in ALOX15 results in increased allele-specific transcription in macrophages through binding of the transcription factor SPI1. Human mutation. 2006;27(1):78-87 (PubMed PMID: 16320347. Epub 2005/12/02. eng).

60. Zheng T, Zhu Z, Wang Z, Homer RJ, Ma B, Riese RJ Jr, et al. Inducible targeting of IL-13 to the adult lung causes matrix metalloproteinase- and cathepsin-dependent emphysema. J Clin Invest. 2000;106(9):1081-93 (PubMed PMID: 11067861. Pubmed Central PMCID: PMC301418. Epub 2000/11/09. eng).

61. Oelgeschlager M, Nuchprayoon I, Luscher B, Friedman AD. $\mathrm{C} / \mathrm{EBP}$, c-Myb, and PU.1 cooperate to regulate the neutrophil elastase promoter. Mol Cell Biol. 1996;16(9):4717-25 (PubMed PMID: 8756629. Pubmed Central PMCID: 231472. Epub 1996/09/01. eng).

62. Phillips B, Veljkovic E, Peck MJ, Buettner A, Elamin A, Guedj $\mathrm{E}$, et al. A 7-month cigarette smoke inhalation study in C57BL/6 mice demonstrates reduced lung inflammation and emphysema following smoking cessation or aerosol exposure from a prototypic modified risk tobacco product. Food and chemical toxicology : an international journal published for the British Industrial Biological Research Association. 2015;(submitted).

63. Ruwanpura SM, McLeod L, Miller A, Jones J, Vlahos R, Ramm G, et al. Deregulated Stat3 signaling dissociates pulmonary inflammation from emphysema in gp130 mutant mice. Am J Physiol Lung Cell Mol Physiol. 2012;302(7):L627-39 (PubMed PMID: 22268122. Epub 2012/01/24. eng). 
64. Pace E, Ferraro M, Di Vincenzo S, Bruno A, Giarratano A, Scafidi V, et al. Cigarette smoke increases BLT2 receptor functions in bronchial epithelial cells: in vitro and ex vivo evidence. Immunology. 2013;139(2):245-55 (PubMed PMID: 23347335. Pubmed Central PMCID: 3647190. Epub 2013/01/26. eng).

65. Profita M, Albano GD, Montalbano AM, Di Sano C, Anzalone G, Gagliardo R, et al. Acetylcholine leads to signal transducer and activator of transcription 1 (STAT-1) mediated oxidative/nitrosative stress in human bronchial epithelial cell line. Biochim Biophys Acta. 2013;1832(12):1949-58 (PubMed PMID: 23811074. Epub 2013/07/03. eng).

66. Di Stefano A, Caramori G, Barczyk A, Vicari C, Brun P, Zanini $A$, et al. Innate immunity but not NLRP3 inflammasome activation correlates with severity of stable COPD. Thorax. 2014;69(6):516-24 (PubMed PMID: 24430176. Pubmed Central PMCID: PMC4219154. Epub 2014/01/17. eng).

67. Kalin TV, Ustiyan V, Kalinichenko VV. Multiple faces of FoxM1 transcription factor: lessons from transgenic mouse models. Cell Cycle. 2011;10(3):396-405 (PubMed PMID: 21270518. Pubmed Central PMCID: 3115014. Epub 2011/01/29. eng).

68. Ren X, Shah TA, Ustiyan V, Zhang Y, Shinn J, Chen G, et al. FOXM1 promotes allergen-induced goblet cell metaplasia and pulmonary inflammation. Mol Cell Biol. 2013;33(2):371-86 (PubMed PMID: 23149934. Pubmed Central PMCID: PMC3554115. Epub 2012/11/15. eng).

69. Natanek SA, Riddoch-Contreras J, Marsh GS, Hopkinson NS, Man WD, Moxham J, et al. Yin Yang 1 expression and localisation in quadriceps muscle in COPD. Archivos de bronconeumologia. 2011;47(6):296-302 (PubMed PMID: 21565439. Epub 2011/05/14. Eng spa).

70. Handeli S, Simon JA. A small-molecule inhibitor of Tcf/betacatenin signaling down-regulates PPARgamma and PPARdelta activities. Mol Cancer Ther. 2008;7(3):521-9 (PubMed PMID: 18347139. Epub 2008/03/19. eng).

71. Heijink IH, de Bruin HG, van den Berge M, Bennink LJ, Brandenburg SM, Gosens R, et al. Role of aberrant WNT signalling in the airway epithelial response to cigarette smoke in chronic obstructive pulmonary disease. Thorax. 2013;68(8):709-16 (PubMed PMID: 23370438. Epub 2013/02/02. eng).

72. Wang R, Ahmed J, Wang G, Hassan I, Strulovici-Barel Y, Hackett NR, et al. Down-regulation of the canonical Wnt betacatenin pathway in the airway epithelium of healthy smokers and smokers with COPD. PLoS One. 2011;6(4):e14793 (PubMed PMID: 21490961. Pubmed Central PMCID: PMC3072378. Epub 2011/04/15. eng).

73. Li J, Dai A, Hu R, Zhu L, Tan S. Positive correlation between PPARgamma/PGC-1alpha and gamma-GCS in lungs of rats and patients with chronic obstructive pulmonary disease. Acta biochimica et biophysica Sinica. 2010;42(9):603-14 (PubMed PMID: 20732852. Epub 2010/08/25. eng).

74. Shen Y, Chen L, Wang T, Wen F. PPARgamma as a Potential Target to Treat Airway Mucus Hypersecretion in Chronic Airway Inflammatory Diseases. PPAR research. 2012;2012:256874. PubMed PMID: 22761606. Pubmed Central PMCID: PMC3385647. Epub 2012/07/05. eng.

75. Lakshmi SP, Reddy AT, Zhang Y, Sciurba FC, Mallampalli RK, Duncan SR, et al. Down-regulated peroxisome proliferator-activated receptor gamma (PPARgamma) in lung epithelial cells promotes a PPARgamma agonist-reversible proinflammatory phenotype in chronic obstructive pulmonary disease (COPD). J Biol Chem. 2014;289(10):6383-93 (PubMed PMID: 24368768. Pubmed Central PMCID: PMC3945305. Epub 2013/12/26. eng).

76. Cosio MG, Majo J. Inflammation of the airways and lung parenchyma in COPD: role of $\mathrm{T}$ cells. Chest. 2002;121(5
Suppl):160S-5S (PubMed PMID: 12010846. Epub 2002/05/16. eng).

77. Majo J, Ghezzo H, Cosio MG. Lymphocyte population and apoptosis in the lungs of smokers and their relation to emphysema. Eur Respir J Off J Eur Soc Clin Respir Physiol. 2001;17(5):946-53 (PubMed PMID: 11488331. Epub 2001/08/ 08. eng).

78. Ma B, Kang MJ, Lee CG, Chapoval S, Liu W, Chen Q, et al. Role of CCR5 in IFN-gamma-induced and cigarette smoke-induced emphysema. J Clin Invest. 2005;115(12):3460-72 (PubMed PMID: 16284650. Pubmed Central PMCID: 1280966. Epub 2005/11/15. eng).

79. D'Hulst AI, Bracke KR, Maes T, De Bleecker JL, Pauwels RA, Joos GF, et al. Role of tumour necrosis factor-alpha receptor p75 in cigarette smoke-induced pulmonary inflammation and emphysema. Eur Respir J Off J Eur Soc Clin Respir Physiol. 2006;28(1):102-12 (PubMed PMID: 16540505. Epub 2006/03/ 17. eng).

80. Fujita M, Shannon JM, Irvin CG, Fagan KA, Cool C, Augustin A, et al. Overexpression of tumor necrosis factor-alpha produces an increase in lung volumes and pulmonary hypertension. Am J Physiol Lung Cell Mol Physiol. 2001;280(1):L39-49 (PubMed PMID: 11133493. Epub 2001/01/03. eng).

81. Lundblad LK, Thompson-Figueroa J, Leclair T, Sullivan MJ, Poynter ME, Irvin CG, et al. Tumor necrosis factor-alpha overexpression in lung disease: a single cause behind a complex phenotype. Am J Respir Crit care medicine. 2005;171(12):1363-70 (PubMed PMID: 15805183. Pubmed Central PMCID: 2718479. Epub 2005/04/05. eng).

82. Wang Z, Zheng T, Zhu Z, Homer RJ, Riese RJ, Chapman HA Jr, et al. Interferon gamma induction of pulmonary emphysema in the adult murine lung. J Exp Med. 2000;192(11):1587-600 (PubMed PMID: 11104801. Pubmed Central PMCID: 2193095. Epub 2000/12/06. eng).

83. Miotto D, Ruggieri MP, Boschetto P, Cavallesco G, Papi A, Bononi I, et al. Interleukin-13 and -4 expression in the central airways of smokers with chronic bronchitis. Eur Respir J Off J Eur Soc Clin Respir Physiol. 2003;22(4):602-8 (PubMed PMID: 14582911. Epub 2003/10/30. eng).

84. Dasgupta A, Neighbour H, Nair P. Targeted therapy of bronchitis in obstructive airway diseases. Pharm Ther. 2013;140(3):213-22 (PubMed PMID: 23845862. Epub 2013/07/13. eng).

85. Eustace A, Smyth LJ, Mitchell L, Williamson K, Plumb J, Singh D. Identification of cells expressing IL-17A and IL-17F in the lungs of patients with COPD. Chest. 2011;139(5):1089-100 PubMed PMID: 20864612. Epub 2010/09/25. eng.

86. Di Stefano A, Caramori G, Gnemmi I, Contoli M, Vicari C, Capelli A, et al. T helper type 17-related cytokine expression is increased in the bronchial mucosa of stable chronic obstructive pulmonary disease patients. Clin Exp Immunol. 2009;157(2):316-24 (PubMed PMID: 19604272. Pubmed Central PMCID: PMC2730858. Epub 2009/07/17. eng).

87. Harrison OJ, Foley J, Bolognese BJ, Long E 3rd, Podolin PL, Walsh PT. Airway infiltration of CD4 + CCR6 + Th17 type cells associated with chronic cigarette smoke induced airspace enlargement. Immunol Lett. 2008;121(1):13-21 (PubMed PMID: 18706444. Epub 2008/08/19. eng).

88. Chen K, Pociask DA, McAleer JP, Chan YR, Alcorn JF, Kreindler JL, et al. IL-17RA is required for CCL2 expression, macrophage recruitment, and emphysema in response to cigarette smoke. PLoS One. 2011;6(5):e20333. PubMed PMID: 21647421. Pubmed Central PMCID: 3103542. Epub 2011/06/08. eng.

89. Kurimoto E, Miyahara N, Kanehiro A, Waseda K, Taniguchi A, Ikeda G, et al. IL-17A is essential to the development of elastaseinduced pulmonary inflammation and emphysema in mice. Respir 
Res. 2013;14:5 (PubMed PMID: 23331548. Pubmed Central PMCID: PMC3564829. Epub 2013/01/22. eng).

90. Churg A, Zhou S, Wright JL. Series "matrix metalloproteinases in lung health and disease": Matrix metalloproteinases in COPD. The European respiratory journal : official journal of the European Society for Clinical Respiratory Physiology. 2012;39(1):197-209 (PubMed PMID: 21920892. Epub 2011/09/17. eng).

91. Yoshida T, Tuder RM. Pathobiology of cigarette smoke-induced chronic obstructive pulmonary disease. Physiological reviews. 2007;87(3):1047-82 (PubMed PMID: 17615396. Epub 2007/07/07. eng).

92. Morris DG, Huang X, Kaminski N, Wang Y, Shapiro SD, Dolganov G, et al. Loss of integrin alpha(v)beta6-mediated TGF-beta activation causes Mmp12-dependent emphysema. Nature. 2003;422(6928):169-73 (PubMed PMID: 12634787. Epub 2003/03/14. Eng).

93. Croker BA, Krebs DL, Zhang JG, Wormald S, Willson TA, Stanley EG, et al. SOCS3 negatively regulates IL-6 signaling in vivo. Nat Immunol. 2003;4(6):540-5 (PubMed PMID: 12754505. Epub 2003/05/20. eng).

94. Croker BA, Metcalf D, Robb L, Wei W, Mifsud S, DiRago L, et al. SOCS3 is a critical physiological negative regulator of
G-CSF signaling and emergency granulopoiesis. Immunity. 2004;20(2):153-65 (PubMed PMID: 14975238. Epub 2004/02/ 21. eng).

95. Wesche H, Henzel WJ, Shillinglaw W, Li S, Cao Z. MyD88: an adapter that recruits IRAK to the IL-1 receptor complex. Immunity. 1997;7(6):837-47 (PubMed PMID: 9430229. Epub 1998/01/16. eng).

96. Zhang X, Shan P, Jiang G, Cohn L, Lee PJ. Toll-like receptor 4 deficiency causes pulmonary emphysema. J Clin Inves. 2006;116(11):3050-9 (PubMed PMID: 17053835. Pubmed Central PMCID: 1616193. Epub 2006/10/21. eng).

97. Doz E, Noulin N, Boichot E, Guenon I, Fick L, Le Bert M, et al. Cigarette smoke-induced pulmonary inflammation is TLR4/ MyD88 and IL-1R1/MyD88 signaling dependent. J Immunol. 2008;180(2):1169-78 (PubMed PMID: 18178857. Epub 2008/01/08. eng).

98. Barnes PJ. The cytokine network in asthma and chronic obstructive pulmonary disease. J Clin Invest. 2008;118:3546-56 (PubMed PMID: 18982161).

99. Vlahos R, Bozinovski S. Recent advances in pre-clinical mouse models of COPD. Clin Sci. 2014;126:253-65 (PubMed PMID: 24144354). 